\title{
A spatially explicit model for predicting the probability of occurrence of zero-catch quadrants in the tuna purse seine fishery of the Eastern Tropical Pacific Ocean
}

\section{Un modelo espacialmente explícito para predecir la ocurrencia de cuadrantes con capturas nulas en la pesquería de túnidos que opera con red de cerco en el océano Pacífico Tropical Oriental}

\author{
Emigdio Marín-Enríquez*1, Xchel G Moreno-Sánchez², Francisco J Urcádiz-Cázares ${ }^{3}$, Enrique \\ Morales-Bojórquez ${ }^{4}$, S Saúl Ramírez-Pérez ${ }^{5}$ \\ ${ }^{1}$ Consejo Nacional de Ciencia y Tecnología-Facultad de Ciencias del Mar, Universidad Autónoma de Sinaloa, \\ Paseo Claussen, S/N, CP 82000, Mazatlán, Sinaloa, Mexico. \\ ${ }^{2}$ Centro Interdisciplinario de Ciencias Marinas del Instituto Politécnico Nacional (IPN), Departamento de \\ Pesquerías y Biología Marina, Av. Instituto Politécnico Nacional, S/N, CP 23090, La Paz, Baja California Sur, \\ Mexico \\ 3 Tecnológico Nacional de México, Departamento de Ciencias Básicas, Boulevard Forjadores de Baja \\ California Sur, no. 4720, CP 23080, La Paz, Baja California Sur, Mexico. \\ ${ }^{4}$ Centro de Investigaciones Biológicas del Noroeste, Av. Instituto Politécnico Nacional, no. 195, Col. Playa \\ Palo de Santa Rita Sur, CP 23090, La Paz, Baja California Sur, Mexico. \\ ${ }^{5}$ Facultad de Ciencias del Mar, Universidad Autónoma de Sinaloa, Paseo Claussen, S/N, CP 82000, Mazatlán, \\ Sinaloa, Mexico. \\ * Corresponding author. E-mail: emarin@uas.edu.mx
}

\begin{abstract}
Null purse seine sets (those in which the catch is zero) are common in every tuna fishery in the world. Current evidence suggests that different environmental factors can influence the occurrence of null sets. In this study, we used a long-term (2003-2015) database from the tuna purse seine fishery in the eastern Pacific Ocean to analyze the temporal and spatial variability of the occurrence of $1^{\circ} \times 1^{\circ}$ quadrants where the retained tuna catch was zero ("null cells"). We fitted a logistic generalized additive model to predict the occurrence of null cells as a function of environmental and operational covariates. Results of the modeling process suggested that high probabilities of null cell occurrence exist mainly in 2 environmentally different zones: the entrance to the Gulf of California, Mexico, and off the coast of Central America. The final statistical model suggested that operational variables (number of sets, type of fishing indicator) are more important to null cell occurrence than environmental factors (sea surface temperature, chlorophyll concentration, sea level anomaly, and El Niño events).
\end{abstract}

Key words: seiners, tuna fisheries, remote sensing, eastern Pacific Ocean.

RESUMEN. Los lances nulos (lances en donde la captura retenida es cero) ocurren de manera común en las pesquerías de túnidos alrededor del mundo. La evidencia actual sugiere que existen distintos factores ambientales que pueden influir en la ocurrencia de este tipo de lances. En el presente trabajo se utilizó una base de datos histórica (2003-2015) de la pesquería de túnidos que opera con red de cerco en el Pacífico Tropical Oriental. Se analizó la variabilidad espaciotemporal de la ocurrencia de cuadrantes de $1^{\circ} \times 1^{\circ}$ en donde la captura retenida fue cero ("cuadrantes nulos"). Se ajustó un modelo aditivo generalizado logístico para predecir la ocurrencia de los cuadrantes nulos en función de distintas variables ambientales y operacionales. Los resultados sugirieron que existen 2 zonas con alta probabilidad de ocurrencia de cuadrantes nulos, las cuales son muy diferentes desde el punto de vista ambiental: la entrada al golfo de California, México, y frente a la costa de Centroamérica. El modelo estadístico final sugirió que los factores operacionales (número de lances, indicador de pesca) son más importantes para determinar la ocurrencia de cuadrantes nulos que los factores ambientales (temperatura superficial del mar, concentración de clorofila, anomalía del nivel del mar, y eventos El Niño).

Palabras clave: buques cerqueros, pesquería de túnidos, sensores remotos, océano Pacífico oriental.

\section{INTRODUCTION}

The purse seine fishery is the most important tuna fishery in the world, accounting for $66 \%-76 \%$ of the global tuna catch in 2010 (Dreyfus-León et al. 2015, McCluney et al. 2019). Of the global tuna catch, the contribution made

\section{INTRODUCCIÓN}

La pesca con red de cerco es la pesquería de túnidos más importante del mundo ya que generó entre el $66 \%$ y $76 \%$ de la captura mundial de túnidos en 2010 (Dreyfus-León et al. 2015, McCluney et al. 2019). De la captura mundial de 
by the Pacific Ocean fishery is by far the most important (Miyake et al. 2004). Around 21\% of tuna catches within the Pacific are made in the eastern Pacific Ocean (EPO), where the purse seine fleet targets mainly yellowfin (Thunnus albacares) and skipjack (Katsuwonus pelamis) and tracks tuna schools using 3 main fishing indicators: dolphins, free-swimming schools, and floating objects (IATTC 2017). In the EPO most yellowfin tuna are caught when sets are made on dolphins and in 2 main high-catch areas, one near the Central American coast $\left(\sim 10^{\circ} \mathrm{S}, 10^{\circ} \mathrm{N}\right)$ and the other near the Baja California Peninsula (centered around $20^{\circ} \mathrm{N}$, $115^{\circ} \mathrm{W}$ ) (IATTC 2017). Most skipjack tuna, on the other hand, are caught in sets on floating objects south of $5^{\circ} \mathrm{N}$ and east of $110^{\circ} \mathrm{W}$ (IATTC 2017).

The tuna species targeted by the purse seine fleet are generally assumed to be capable of performing long-distance migrations (see, for example, Itoh et al. 2003), although the movement patterns of most species are not yet fully understood. Some studies, however, have demonstrated that some of the most important tuna species show some degree of fidelity to certain areas, a behavior that could result in patchy population distribution patterns. For example, tagging studies of yellowfin tuna have shown that individuals usually remain within $1,800 \mathrm{~km}$ of the release location (IATTC 2017). The discrete-population hypothesis for yellowfin tuna inhabiting the Pacific Ocean is also supported by the global genetic analysis conducted by Pecoraro et al. (2018).

On another note, the horizontal movements of the skipjack tuna appear to be restricted to a few hundred kilometers, although it is possible that there is only one skipjack population in the Pacific Ocean and that the exchange of individuals is thus occurring at local scales (IATTC 2017). The rate of exchange of skipjack individuals between the EPO and other areas in the Pacific Ocean cannot be quantified with the tagging data that is currently available (IATTC 2017).

Recent studies have shown that fishers track small-scale oceanographic features where important tuna congregations occur, such as thermal fronts and eddies (Scales et al. 2018). Torres-Orozco et al. (2005) suggested that yellowfin tuna occupied the warm side of the thermal fronts that occurred in the EPO off Cabo Corrientes $\left(\sim 20^{\circ} \mathrm{N}\right.$, $\left.106^{\circ} \mathrm{W}\right)$, Mexico. Jiménez-Tello (2014) showed that most unassociated purse seine sets targeting yellowfin tuna in the Pacific Ocean, off northwestern Mexico, were carried out in waters with sea surface temperatures of $\sim 22{ }^{\circ} \mathrm{C}$ and negative sea surface height anomalies, indicating that yellowfin tuna schools are associated with cyclonic eddies. Mugo et al. (2010) suggested that the skipjack tuna preferred habitat is bounded by sea surface temperatures between 20.5 and $26.0^{\circ} \mathrm{C}$, relatively low chlorophyll $a$ concentrations, and positive sea surface height anomalies, indicating that the skipjack tuna likewise inhabits zones with thermal fronts and eddies. túnidos, la contribución de la pesquería del océano Pacífico es, por mucho, la más importante (Miyake et al. 2004). Alrededor del $21 \%$ de las capturas de túnidos se realizan en el océano Pacífico oriental (OPO), donde la flota que opera con red de cerco se dirige a pescar principalmente atún aleta amarilla (Thunnus albacares) y barrilete (Katsuwonus pelamis) y rastrea cardúmenes de túnidos con 3 indicadores de pesca: delfines, cardúmenes libres y objetos flotantes (IATTC 2017). En el OPO la mayoría de los atunes aleta amarilla se capturan cuando los lances se realizan sobre delfines y en 2 áreas principales de alta captura, una cerca de la costa de Centroamérica $\left(\sim 10^{\circ} \mathrm{S}, 10^{\circ} \mathrm{N}\right)$ y otra cerca de la península de Baja California (centrado alrededor $20^{\circ} \mathrm{N}, 115^{\circ} \mathrm{W}$ ) (IATTC 2017). Por otro lado, la mayoría de los barriletes son capturados con lances sobre objetos flotantes al sur de $5^{\circ} \mathrm{N}$ y al este de $110^{\circ} \mathrm{W}$ (IATTC 2017).

Se considera que, por lo general, las especies de túnidos a las cuales se dirige la flota cerquera son capaces de realizar migraciones de larga distancia (ver, por ejemplo, Itoh et al. 2003), aunque los patrones de movimiento de la mayoría de las especies aún no se conocen en su totalidad. Sin embargo, algunos estudios han demostrado que las especies más importantes de túnidos presentan cierto grado de fidelidad a ciertas áreas, un comportamiento que podría resultar en un patrón de distribución de sus poblaciones fragmentado. Por ejemplo, los estudios de marcaje del atún aleta amarilla han demostrado que los individuos, generalmente, permanecen a menos de 1,800 km de la locación de liberación (IATTC 2017). En el caso del atún aleta amarilla que habita el océano Pacífico, la hipótesis de una población discreta también es respaldada por el análisis genético global realizado por Pecoraro et al. (2018).

Por otro lado, los movimientos horizontales del barrilete parecen estar restringidos a unos pocos cientos de kilómetros, aunque es posible que solo exista una población de barrilete en el océano Pacífico y, por tanto, que el intercambio de individuos esté ocurriendo a escalas locales (IATTC 2017). La tasa de intercambio de individuos de barrilete entre el OPO y otras áreas del océano Pacífico no puede ser cuantificada con los datos de marcaje que están disponibles actualmente (IATTC 2017).

Estudios recientes han demostrado que los pescadores rastrean fenómenos oceanográficos de pequeña escala donde ocurren congregaciones importantes de túnidos, tales como los frentes térmicos y los remolinos (Scales et al. 2018). TorresOrozco et al. (2005) sugirieron que el atún aleta amarilla ocupó la parte cálida de los frentes térmicos que ocurrieron en el OPO frente a cabo Corrientes $\left(\sim 20^{\circ} \mathrm{N}, 106^{\circ} \mathrm{W}\right)$, México. Jiménez-Tello (2014) demostró que la mayoría de los lances no asociados dirigidos al atún aleta amarilla en el océano Pacífico, frente al noroeste de México, se realizaron en aguas con temperaturas superficiales de $\sim 22{ }^{\circ} \mathrm{C}$ y anomalías negativas de la altura de la superficie del mar, lo cual indica que los cardúmenes del atún aleta amarilla están asociados con los remolinos ciclónicos. Mugo et al. (2010) sugirieron que el 
The purse seine fleet operating in the EPO is perhaps one of the most technologically advanced fishing fleets in the world because it uses state-of-the-art technology (helicopters, speedboats, bird sonars, fish aggregating devices equipped with GPS, and echo sounders) to track tunas (IATTC 2004). Despite the use of advanced technology, purse seine maneuvers often result in null sets (purse seine maneuvers where the retained tuna catch is zero), even when tunas are numerous and concentrated in small areas (Fonteneau et al. 2008).

Previous works have demonstrated that fishing on free-swimming tuna schools is an important cause of the occurrence of null sets (Sarralde et al. 2005, Dreyfus-León and Mejía 2009, Chassot et al. 2013). However, and despite the obvious economic impact of zero-catch purse seine maneuvers, little research has been conducted to elucidate which environmental factors are influencing the occurrence of these phenomena. For the Spanish and French purse seine fleets operating in the Indian Ocean, Guillotreau et al. (2011) suggested that fisher preference for free-swimming or fish-aggregating-device (FAD) sets (and the associated percentage of null sets, which is higher on free-swimming schools) can vary with certain environmental events, such as El Niño/Southern Oscillation (ENSO), but they also observed that this variation was high with changes in available technology and the experience of fishers. Dreyfus-León et al. (2015) concluded that the deepening of the thermocline was the main cause of null sets in Pacific Ocean waters off Mexico and Central America, that these type of sets were more likely to occur when made on free-swimming schools during ENSO events, and that most of these sets occurred at the entrance to the Gulf of California.

Different statistical approaches have been used to link the distribution or presence/absence of large pelagic fishes to environmental features. For example, with data from the Japanese longline fishery and satellite-derived environmental data, Zainuddin et al. (2008) used a combination of generalized linear models (GLMs) and generalized additive models (GAMs) to predict potential albacore (Thunnus alalunga) fishing grounds. Using incidental catch data from the purse seine fleet in the eastern Tropical Pacific Ocean, Martínez-Rincón et al. (2012) found that GAMs and boosted regression trees had nearly identical predictive performance when modeling the probability of occurrence of wahoo (Acanthocybium solandri). Marín-Enríquez et al. (2018) used a presence/absence GAM approach to depict the potential hot spots and migration patterns of dolphinfish (Coryphaena spp.) in the EPO off Mexico, also using incidental catch data from the purse seine tuna fishery and satellite-derived oceanographic data.

The main working hypothesis of this study is that variations in the marine environment are the main cause of the occurrence of null sets made by the purse seine fleet that operated in the EPO from 2003 to 2015. A logistic GAM was fitted to data on the presence/absence of null cells in order to hábitat preferencial del barrilete está delimitado por temperaturas superficiales del mar de entre 20.5 y $26.0^{\circ} \mathrm{C}$, concentraciones relativamente bajas de clorofila $a$ y anomalías positivas de la altura de la superficie del mar, lo cual indica que el atún barrilete, al igual que el atún aleta amarilla, habita zonas con frentes térmicos y remolinos.

La flota cerquera que opera en el OPO es probablemente una de las flotas pesqueras más avanzadas tecnológicamente del mundo porque usa tecnologías de vanguardia (helicópteros, lanchas motoras, sonares de pájaros, dispositivos para el agrupamiento de peces equipados con GPS, y ecosondas) para rastrear túnidos (IATTC 2004). A pesar del uso de tecnologías avanzadas, las maniobras de las redes de cerco con frecuencia resultan en lances nulos (maniobras en las cuales la captura retenida es cero), aun cuando el atún se encuentra en cantidades numerosas y se concentra en áreas pequeñas (Fonteneau et al. 2008).

Estudios anteriores han demostrado que la pesca sobre cardúmenes de túnidos libres es una de las causas principales de la ocurrencia de lances nulos (Sarralde et al. 2005, Dreyfus-León y Mejía 2009, Chassot et al. 2013). Sin embargo, y a pesar del obvio impacto económico de las maniobras de la red de cerco que resultan en capturas nulas, poca investigación se ha realizado para elucidar cuáles son los factores ambientales que influyen en la ocurrencia de estos fenómenos. Para las flotas cerqueras españolas y francesas que operan en el océano Índico, Guillotreau et al. (2011) sugirieron que la preferencia de los pescadores por los lances sobre cardúmenes libres o con dispositivos de agregación de peces (DAP) (y el porcentaje asociado de lances nulos, que es mayor sobre los cardúmenes libres) puede variar con ciertos eventos ambientales, como El Niño/Oscilación del Sur (ENOS), pero también observaron que esta variación era alta con los cambios en la tecnología disponible y la experiencia de los pescadores. Dreyfus-León et al. (2015) concluyeron que la profundización de la termoclina fue la causa principal de los lances nulos en las aguas del océano Pacífico frente a México y Centroamérica, que este tipo de lances tenían más probabilidades de ocurrir cuando se realizaban sobre cardúmenes libres durante los eventos ENOS y que la mayoría de estos lances ocurrieron en la entrada al golfo de California.

Se han utilizado diferentes métodos estadísticos para vincular la distribución o presencia/ausencia de grandes peces pelágicos con las características ambientales. Por ejemplo, con los datos de la pesquería de palangre japonesa y los datos ambientales derivados de satélite, Zainuddin et al. (2008) utilizaron una combinación de modelos lineales generalizados (MLG) y modelos aditivos generalizados (MAG) para predecir las posibles zonas de pesca para el atún blanco (Thunnus alalunga). Utilizando los datos de la captura incidental de la flota cerquera en el océano Pacífico Tropical Oriental, Martínez-Rincón et al. (2012) encontraron que los MAG y los árboles de regresión aumentados tenían un rendimiento predictivo casi idéntico al modelar la probabilidad de ocurrencia de individuos de peto (Acanthocybium solandri). 
assess how and to what extent the probability of occurrence of null cells is influenced by variations in the marine environment and by spatial and operational factors inherent of the tuna purse seine fleet. The final GAM presented in this paper could serve as a decision-making tool to minimize the number of purse seine sets that are required to reach the fixed fishing quotas set for the purse seine fleet. The operational costs for the purse seine fleet are high; for example, the mean cost of a purse seine set carried out by an Ecuadorian vessel is around 4,120 USD (mean total operational cost of 642,700 USD per year per vessel, mean of 6 trips per year per vessel, mean of 26 sets per trip per vessel), and the mean catch per set is $20 \mathrm{t}$ (Bucaram 2017). Therefore, besides the obvious economic impact (minimizing fishing effort would certainly result in lowering the operational cost of each fishing trip), minimizing the fishing effort exerted by the purse seine fleet could also have an important ecological impact because the bycatch from purse seine maneuvers, which includes several species of sharks, billfish, sea turtles, and marine mammals (IATTC 2017), would also be diminished.

\section{MATERIALS AND METHOdS}

\section{Study area}

The study area covers the entire eastern Tropical Pacific Ocean (ETPO). In the northern area, large-scale circulation is dominated by the California Current, which is the eastern extension of the North Pacific Subtropical Gyre (Badán 1997). Ocean circulation north and south of the equator is dominated by the Equatorial Current System. North of the equator, the North Equatorial Countercurrent flows eastward and the North Equatorial Current flows westward as the extension of the main branch of the California Current (Fiedler and Talley 2006). South of the equator, the South Equatorial Current is the main feature of the large-scale ocean circulation, and coastal circulation near South America is dominated by the Peru Current, also known as the Humboldt Current (Kessler 2006).

Several smaller-scale oceanographic features occur in the study area. In the northern zone the Eastern Pacific Warm Pool, centered at around $10^{\circ} \mathrm{N}$ and $100^{\circ} \mathrm{W}$, is one of the main features and it is characterized by year-round high temperatures $\left(>27.5^{\circ} \mathrm{C}\right)$ (Fiedler and Talley 2006), as a result of strong stratification due to poor wind mixing (Wang and Enfield 2001). Three coastal mountain-gap wind jets occur seasonally in the study area, one in the Gulf of Tehuantepec (Mexico), one in the Gulf of Papagayo (Costa Rica), and the other one in the Gulf of Panama (Panama), and they are more evident during the boreal winter (Trasviña and Barton 2008) (Fig. 1). Centered at around $9^{\circ} \mathrm{N}$ and $90^{\circ} \mathrm{W}$ is the Costa Rica Dome, which is a ridge in the thermocline caused by anticyclonic circulation. This dome is affected by these coastal wind jets (Fiedler 2002). Associated with this feature, off Central America, is the Costa Rica Coastal Current, a northerly
Marín-Enríquez et al. (2018) utilizaron un MAG de presencia/ ausencia para representar los posibles centros y los patrones de migración del dorado (Coryphaena spp.) en el OPO frente a México, junto con el uso de los datos de captura incidental de la pesquería de túnidos con redes de cerco y datos oceanográficos derivados de satélite.

La principal hipótesis de trabajo de este estudio es que las variaciones en el entorno marino son la causa principal de la ocurrencia de lances nulos realizados por la flota cerquera que operó en el OPO de 2003 a 2015. Se ajustó un MAG logístico a los datos sobre la presencia/ausencia de cuadrantes nulos para evaluar cómo y en qué medida la probabilidad de la ocurrencia de cuadrantes nulos es influenciada por las variaciones en el ambiente marino y por los factores espaciales y operativos inherentes a la flota cerquera dirigida a túnidos. El MAG final presentado en este trabajo podría servir como una herramienta de toma de decisiones para minimizar el número de lances de redes de cerco que se requieren para alcanzar las cuotas fijas de pesca establecidas para la flota cerquera. Los costos operativos para la flota cerquera son altos; por ejemplo, el costo promedio de un lance cerquero realizado por un barco ecuatoriano es de alrededor de 4,120 dólares (costo operativo total promedio de 642,700 dólares por año por barco, promedio de 6 campañas por año por barco, promedio de 26 lances por campaña por barco) y la captura media por lance es de 20 t (Bucaram 2017). Además del evidente impacto económico (minimizar el esfuerzo pesquero ciertamente reduciría el costo operativo de cada campaña de pesca), minimizar el esfuerzo pesquero ejercido por la flota cerquera también podría tener un impacto ecológico importante porque la captura incidental de las maniobras de la red de cerco, que incluye varias especies de tiburones, peces picudos, tortugas marinas y mamíferos marinos (IATTC 2017), también disminuiría.

\section{MATERIALES Y MÉTODOS}

\section{Área de estudio}

El área de estudio cubre todo el océano Pacífico Tropical Oriental (OPTO). En la parte norte, la circulación de gran escala es dominada por la corriente de California, que es la extensión oriental del Giro Subtropical del Pacífico Norte (Badán 1997). La circulación del océano al norte y al sur del ecuador es dominada por el Sistema de la Corriente Ecuatorial. Al norte del ecuador, la contracorriente Ecuatorial del Norte fluye hacia el este y la corriente Ecuatorial del Norte fluye hacia el oeste como la extensión de la rama principal de la corriente de California (Fiedler y Talley 2006). Al sur del ecuador, la corriente Ecuatorial del Sur domina la circulación oceánica de gran escala, mientras que la circulación costera cerca de Sudamérica es dominada por la corriente del Perú, también conocida como la corriente de Humboldt (Kessler 2006). 
warm surface current that turns westward near the Gulf of Tehuantepec owing to the wind jets that occur in this region (Kessler 2006). The equatorial cold tongue, an extension of the Peru Current, occurs south of the equator, producing strong thermal fronts in the equatorial upwelling system (Fiedler and Talley 2006).

\section{Fishery database}

We analyzed a database from the international tuna purse seine fleet operating in the EPO from August 2003 to December 2015. The database was obtained from the Inter-American Tropical Tuna Commission (IATTC) website (PublicPSTunaSetType 1958-2016). Data here were either gathered at sea by observers aboard the Class- 6 purse seine tuna vessels $\left(>435 \mathrm{~m}^{3}\right.$ storage capacity) or extracted from vessel logbooks when observer data were not available. The database included the retained catch (in metric tons) for 6 tuna species, namely Pacific bluefin (Thunnus orientalis), black skipjack (Euthynnus lineatus), yellowfin (T. albacares), bigeye (Thunnus obesus), skipjack (K. pelamis), and albacore (T. alalunga); a tuna group labeled as Sarda, which included striped bonitos (Sarda chiliensis and Sarda orientalis); and a group classified as "unidentified tunas". This database also included the number of purse seine sets, temporal (month, year) and spatial (latitude, longitude) variables, and the fishing indicator (SetType: dolphin, floating objects, and free-swimming schools), all aggregated in monthly $1^{\circ} \times 1^{\circ}$ quadrants in a grid that covered the ETPO, from $24^{\circ} \mathrm{S}$ to $45^{\circ} \mathrm{N}$ and from $150^{\circ} \mathrm{W}$ to $70^{\circ} \mathrm{W}$ (Fig. 1). Because the IATTC database was aggregated in $1^{\circ} \times 1^{\circ}$ quadrants, we were unable to analyze the occurrence of null sets. We therefore had to work at a coarser spatial level, defining null cells as those $1^{\circ} \times 1^{\circ}$ quadrants where the total monthly retained catch was zero for all tuna species, including the unidentified group.

\section{Environmental database}

Monthly mean satellite-derived data of sea surface temperature (SST, degrees Celsius), surface chlorophyll $a$ concentration (Chla, milligrams per cubic meter), sea level anomaly (SLA, meters), and the Oceanic Niño Index (ONI) were used to assess possible environmental patterns in oceanic zones where null cells were more common. Both SST and Chla were obtained from the US National Oceanic and Atmospheric Administration's ERDDAP data server (ERDDAP 2003-2016, 2003-2020), with a monthly temporal resolution and a $0.1^{\circ}$ and $0.04^{\circ}$ spatial resolution, respectively. Sea level anomaly data was obtained from the AVISO website (AVISO+ Satellite Altimetry Data 19932020), with a weekly temporal resolution and a $0.25^{\circ}$ spatial resolution. We decided to use SST because it affects the physiology, distribution, and vulnerability to certain fishing
Varios fenómenos oceanográficos de menor escala se producen en el área de estudio. En la zona norte, la alberca cálida del Pacífico oriental, centrada alrededor de $10^{\circ} \mathrm{N}$ y $100^{\circ} \mathrm{W}$, es uno de los fenómenos principales y se caracteriza por presentar altas temperaturas durante todo el año $\left(>27.5^{\circ} \mathrm{C}\right.$ ) (Fiedler y Talley 2006), como resultado de la fuerte estratificación debido a que la mezcla inducida por el viento es débil (Wang y Enfield 2001). Tres chorros de viento costeros inducidos por pasos de montañas ocurren estacionalmente en el área de estudio, uno en el golfo de Tehuantepec (México), uno en el golfo de Papagayo (Costa Rica) y otro en el golfo de Panamá (Panamá), y son más evidentes durante el invierno boreal (Trasviña y Barton 2008) (Fig. 1). El Domo Térmico de Costa Rica, que es una cresta en la termoclina causada por la circulación anticiclónica, está centrado alrededor de $9^{\circ} \mathrm{N}$ y $90^{\circ} \mathrm{W}$. Este domo es afectado por estos chorros de viento (Fiedler 2002). Asociado a este fenómeno, frente a Centroamérica, se encuentra la corriente costera de Costa Rica, una corriente cálida superficial que fluye hacia el norte y gira hacia el oeste cerca del golfo de Tehuantepec debido a los chorros de viento que ocurren en esta región (Kessler 2006). La lengüeta ecuatorial fría, una extensión de la corriente del Perú, ocurre al sur del ecuador y produce fuertes frentes térmicos en el sistema de surgencias ecuatorial (Fiedler y Talley 2006).

\section{Base de datos pesqueros}

Analizamos una base de datos de la flota internacional de túnidos que operó con redes de cerco en el OPO desde agosto de 2003 hasta diciembre de 2015. La base de datos se obtuvo del sitio web de la Comisión Interamericana del Atún Tropical (CIAT) (PublicPSTunaSetType 1958-2016). Los datos aquí fueron recopilados en el mar por observadores a bordo de los barcos atuneros cerqueros Clase $6\left(>435 \mathrm{~m}^{3}\right.$ de capacidad de bodega) o fueron extraídos de los diarios de pesca de los barcos cuando los datos de observadores no estaban disponibles. La base de datos incluyó la captura retenida (en toneladas métricas) para 6 especies de túnidos, específicamente atún aleta azul (Thunnus orientalis), barrilete negro (Euthynnus lineatus), atún aleta amarilla (T. albacares), patudo (Thunnus obesus), barrilete (K. pelamis) y atún blanco (T. alalunga); un grupo de túnidos etiquetado como Sarda, el cual incluyó bonitos rayados (Sarda chiliensis y Sarda orientalis); y un grupo clasificado como "atunes no identificados”. Esta base de datos también incluyó el número de lances de las redes de cerco, variables temporales (mes, año) y espaciales (latitud, longitud), y el indicador de pesca (tipo de lance: delfín, objetos flotantes y cardúmenes libres), todos agregados en cuadrantes mensuales de $1^{\circ} \times 1^{\circ}$ en una cuadrícula que cubría el OPTO, de $24^{\circ} \mathrm{S}$ a $45^{\circ} \mathrm{N}$ y de $150^{\circ} \mathrm{W}$ a $70^{\circ} \mathrm{W}$ (Fig. 1). Debido a que la base de datos de la CIAT estaba conformada en cuadrantes de $1^{\circ} \times 1^{\circ}$, no pudimos analizar la ocurrencia de lances nulos. Por lo tanto, tuvimos que trabajar con una resolución espacial más amplia, y definimos como 
gears of different tuna species (Brill 1994). Surface Chla was used as a proxy for prey availability and to distinguish coastal from oceanic waters (Farrell et al. 2014), and SLA was used as an indicator of certain mesoscale ocean features that can influence thermocline depth, such as eddies and thermal fronts (Zainuddin et al. 2008). We also used ONI because El Niño conditions are known to alter thermocline depth (McPhaden 1999), and this variable has been highlighted as one of the main factors that are responsible for zero-catch tuna sets in northwestern Mexico (Dreyfus-León et al. 2015). cuadrantes nulos a aquellos cuadrantes de $1^{\circ} \times 1^{\circ}$ donde la captura retenida mensual total era cero para todas las especies de túnidos, incluido el grupo no identificado.

\section{Base de datos ambientales}

Los datos promedio mensuales derivados de satélite de la temperatura superficial del mar (TSM, centígrados), la concentración de clorofila $a$ superficial (Cla, miligramos por metro cúbico), la anomalía del nivel del mar (ANM, metros) y el Índice Oceánico de El Niño (ION) se utilizaron para
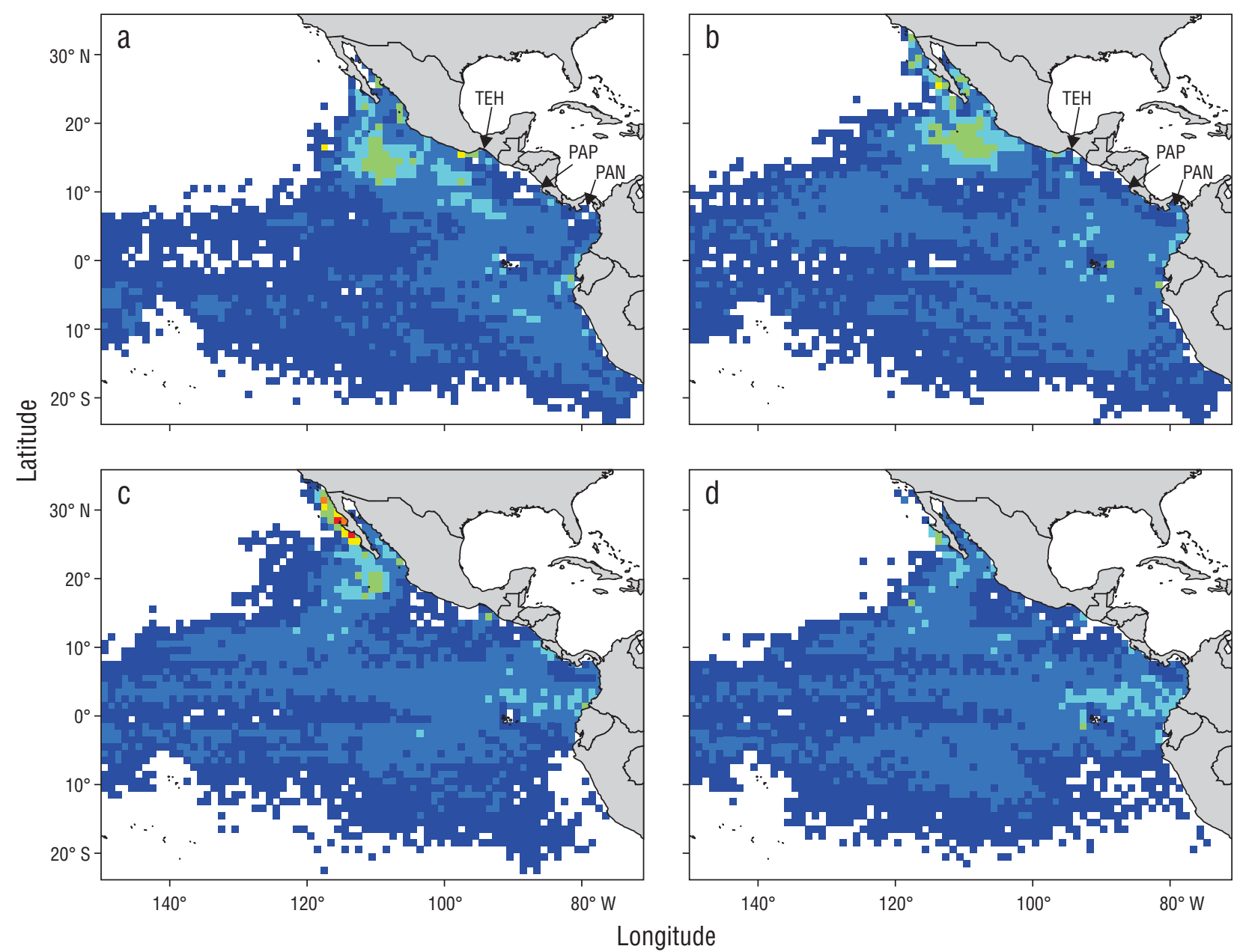

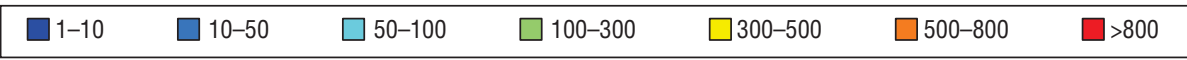

Figure 1. Spatiotemporal distribution of fishing effort (number of sets) exerted by Class- 6 tuna purse seine ships ( $>435 \mathrm{~m}^{3}$ storage capacity) from August 2003 to December 2015. Panels show data for the first (January-March) (a), second (April-June ) (b), third (July-September) (c), and fourth (October-December) (d) quarters of the year. Arrows in (a) and (b) depict the seasonal wind jets: Tehuantepec (TEH), Papagayo (PAP), and Panama (PAN). Color scale indicates number of sets. White color indicates zones where no fishing effort was observed.

Figura 1. Distribución espaciotemporal del esfuerzo pesquero (número de lances) ejercidos por las embarcaciones de túnidos que operan con red de cerco Clase 6 (>435 $\mathrm{m}^{3}$ de capacidad de bodega) desde agosto de 2003 hasta diciembre de 2015. Los paneles muestran los datos para el primer (enero-marzo) (a), segundo (abril-junio) (b), tercero (julio-septiembre) (c) y cuarto (octubre-diciembre) (d) trimestre del año. Las flechas en (a) y (b) representan los chorros de viento estacionales: Tehuantepec (TEH), Papagayo (PAP) y Panamá (PAN). La escala de colores indica el número de lances. El color blanco indica zonas en las que no se observó esfuerzo pesquero. 
Marín-Enríquez et al.: Modeling null-cell occurrence for a tuna purse seine fishery

\section{Statistical analysis}

\section{Model building}

The general structure of a logistic GAM including continuous variables and a categorical variable is given by

$$
\operatorname{logit}\left(P_{i}\right)=\log \left[\frac{P_{i}}{1-P_{i}}\right]=\alpha+\sum_{j=1}^{n} f_{j}\left(X_{i}\right)+\sum_{k=1}^{n} \beta_{k} Z_{i k},
$$

where $P$ is the binomial distribution probability of occurrence of null cells $\left(1\right.$ if the retained catch in the $i$-th $1^{\circ} \times 1^{\circ}$ cell was zero, and 0 otherwise), and it is modelled as the sum of $n$ smooth functions $(f)$ of the continuous variable $x$ and the categorical variable $z$ that has $k$ levels.

For our model, the continuous variables were the environmental (SST, Chla, SLA, ONI), temporal (month, year), and operational (number of sets) variables and the categorical variable was the type of set (3 levels: dolphin, unassociated schools, floating objects). To minimize the problems associated with stepwise model building, we entered the covariates in an order that was established at the start of the modeling process, following the order suggested by Marín-Enríquez et al. (2018): (a) environmental variables; (b) operational variables (number of sets and type of set); (c) temporal variables, used to account for seasonal and interannual differences in the occurrence of null cells; and (d) spatial covariates, used to account for the spatial setting and to reduce the potential bias induced by spatial correlation. Additionally, we analyzed the interactions between latitude, longitude, and year to account for potential spatiotemporal differences in how the purse seine was set, which could affect the probability of occurrence of a null cell (Bigelow et al. 2002, Su et al. 2008). We retained those covariates that resulted in a decrease of at least 2 Akaike information criteria (AIC) units associated with significant statistical increase in explained deviance (Burnham and Anderson 2002). Because the use of covariates that are highly correlated can be confusing when interpreting modeling results (Zuur et al. 2009), we tested the models for potential multicollinearity amongst environmental variables using the concurvity function of the R mcgv package (Wood 2006). Model building was performed using the gam function of the mgcv package (Wood 2006) in the R environment (R Core Team 2016).

\section{Model validation}

Model validation was conducted using a random data splitting strategy. We split the database into 2 different datasets: the "training" dataset, which included $75 \%$ of the observations (chosen randomly), and the "validation" dataset, which included the remainder $25 \%$. We fitted the GAM using the training dataset and then used the final model to make predictions based on the validation dataset. We used these predictions to evaluate model performance by calculating the area evaluar posibles patrones ambientales en las zonas oceánicas donde las cuadrantes nulos eran más comunes. Los datos de TSM y Cla se obtuvieron del servidor de datos ERDDAP de la Oficina Nacional de Administración Oceánica y Atmosférica de EUA (ERDDAP 2003-2016, 2003-2020), con una resolución temporal mensual y una resolución espacial de $0.1^{\circ} \mathrm{y}$ $0.04^{\circ}$, respectivamente. Los datos de la ANM se obtuvieron del sitio web AVISO (AVISO+ Satellite Altimetry Data 19932020), con una resolución temporal semanal y una resolución espacial de $0.25^{\circ}$. Decidimos usar la TSM porque afecta la fisiología, la distribución y la vulnerabilidad a ciertos artes de pesca de diferentes especies de túnidos (Brill 1994). La Cla superficial se usó como un indicador de la disponibilidad de presas y para distinguir las aguas costeras de las oceánicas (Farrell et al. 2014), y la ANM se utilizó como indicador de ciertos fenómenos oceánicos de mesoescala que pueden influir en la profundidad de la termoclina, como los remolinos y los frentes térmicos (Zainuddin et al. 2008). También usamos el ION porque se sabe que las condiciones de El Niño alteran la profundidad de la termoclina (McPhaden 1999), y esta variable se ha destacado como uno de los principales factores responsables de los lances con captura nula de túnidos en el noroeste de México (Dreyfus-León et al. 2015).

\section{Análisis estadístico}

\section{Construcción del modelo}

La estructura general de un MAG logístico que incluye variables continuas y una variable categórica está dado por

$$
\operatorname{logit}\left(P_{i}\right)=\log \left[\frac{P_{i}}{1-P_{i}}\right]=\alpha+\sum_{j=1}^{n} f_{j}\left(X_{i}\right)+\sum_{k=1}^{n} \beta_{k} Z_{i k},
$$

donde $P$ es la probabilidad de distribución binomial de la ocurrencia de cuadrantes nulos ( 1 si la captura retenida en el cuadrante $i$-ésimo de $1^{\circ} \times 1^{\circ}$ era cero, y 0 en caso contrario), y se modela como la suma de $n$ funciones suavizadas $(f)$ de la variable continua $x$ y la variable categórica $z$ que tiene $k$ niveles.

Para nuestro modelo, las variables continuas fueron las variables ambientales (TSM, Cla, ANM, ION), temporales (mes, año) y operacionales (número de lances) y la variable categórica fue el tipo de lance (3 niveles: delfín, cardúmenes no asociados, objetos flotantes). Para minimizar los problemas asociados con la construcción de modelos paso a paso, ingresamos las covariables en un orden que se estableció al comienzo del proceso de modelado, de acuerdo con el orden sugerido por Marín-Enríquez et al. (2018): (a) variables ambientales; (b) variables operativas (número de lances y tipo de lance); (c) variables temporales, utilizadas para explicar las diferencias estacionales e interanuales en la ocurrencia de cuadrantes nulos; y (d) covariables espaciales, utilizadas para explicar la configuración espacial y para reducir el sesgo potencial inducido por la correlación 
under the receiver operating characteristics (AUROC) curve, a value for the probability ( $0-1)$ of correctly discriminating absence from presence of null cell occurrence. This validation/evaluation approach has been successfully used in similar studies (Farrell et al. 2014).

\section{Spatial predictions}

To highlight potential seasonal changes in spatial distribution of null cells, we made predictions of the probability of occurrence of these cells for the whole study area and for the period from August 2003 to December 2015. The environmental database was used in these predictions to ensure predicted values in the entire spatial range of operations by the purse seine fleet. For predictions, we used the mean number of total sets in each cell and a random type of set for the whole study period to detect if certain environmental conditions could be favoring the presence of null cells. Monthly maps for the most representative months of each quarter of the year (February, May, August, and November) were constructed to assess seasonal variation of null cell occurrence. These maps should be interpreted as quarterly means of the probability of occurrence of null cells for the period from August 2003 to December 2015. To highlight the importance of each type of fishing indicator, we also simulated 3 scenarios, as if all fishing sets were made on each of the different fishing indicators (dolphin, unassociated or free-swimming tunas, and floating objects). This resulted in a mean map of null cell occurrence for the whole study period for each type of set. Additionally, to depict the possible effect of ENSO events on the spatial distribution of occurrence of null cells, we created mean maps for 2011 and 2015, when mean ONI values were lowest and highest, respectively.

\section{RESUltS}

\section{Fishing effort}

During the first 2 quarters of the year, most fishing effort by the purse seine tuna fleet was distributed off Cabo Corrientes, Mexico $\left(20^{\circ} \mathrm{N}, 115^{\circ} \mathrm{W}\right)$, where a patch of $>100$ purse seine sets was observed. Isolated quadrants with high fishing effort (>300 sets) were observed in the northern part of the Gulf of Tehuantepec $\left(\sim 15^{\circ} \mathrm{N}, 98^{\circ} \mathrm{W}\right)$ during the first quarter and off the western coast of the Baja California Peninsula $\left(\sim 24^{\circ} \mathrm{N}, 117^{\circ} \mathrm{W}\right)$ during the second quarter (Fig. 1a, b). During the boreal summer (July-September) most fishing effort was concentrated near the Baja California Peninsula (quadrants with $>300$ sets) and around the Revillagigedo Archipelago $\left(\sim 18^{\circ} \mathrm{N}, 115^{\circ} \mathrm{W}\right.$; quadrants with $>100$ sets $)$ (Fig. 1c). In the last quarter of the year, the most important fishing ground was observed just above the imaginary equator line, across a band of quadrants with 50-100 sets that extended from the coast of Central America to $\sim 98^{\circ} \mathrm{W}$ (Fig. 1d). espacial. Además, analizamos las interacciones entre la latitud, la longitud y el año para cuantificar diferencias espaciotemporales potenciales en cómo se lanzó la red de cerco, ya que esto podría afectar la probabilidad de ocurrencia de un cuadrante nulo (Bigelow et al. 2002, Su et al. 2008). Conservamos aquellas covariables que resultaron en la disminución de al menos 2 unidades de criterios de información de Akaike (CIA) asociadas con un aumento estadístico significativo en la variabilidad explicada (Burnham y Anderson 2002). Debido a que el uso de covariables que están altamente correlacionadas puede ser confuso al interpretar los resultados del modelado (Zuur et al. 2009), probamos la multicolinealidad potencial entre las variables ambientales de los modelos utilizando la función concurvity del paquete de R mcgv (Wood 2006). La construcción del modelo se realizó utilizando la función gam del paquete mgcv (Wood 2006) en el ambiente R ( $\mathrm{R}$ Core Team 2016).

\section{Validación del modelo}

La validación del modelo se realizó utilizando una estrategia de división aleatoria de datos. Dividimos la base de datos en 2 conjuntos de datos diferentes: el conjunto de datos de "entrenamiento", que incluyó el 75\% de las observaciones (elegidas aleatoriamente), y el conjunto de datos de "validación", que incluyó el 25\% restante. Ajustamos el MAG usando el conjunto de datos de entrenamiento y posteriormente usamos el modelo final para hacer predicciones basadas en el conjunto de datos de validación. Utilizamos estas predicciones para evaluar la eficiencia del modelo calculando el área bajo la curva de las características operativas del receptor (ABCCOR), un valor para la probabilidad $(0-1)$ de discriminar correctamente la ausencia de la presencia de la ocurrencia de cuadrantes nulos. Este método de validación/ evaluación se ha utilizado de manera exitosa en estudios similares (Farrell et al. 2014).

\section{Predicciones espaciales}

Para resaltar los potenciales cambios estacionales en la distribución espacial de los cuadrantes nulos, realizamos predicciones de la probabilidad de ocurrencia de estos cuadrantes para toda el área de estudio y para el periodo de agosto de 2003 a diciembre de 2015. Se usó la base de datos ambientales para estas predicciones para garantizar valores de predicción en toda la distribución espacial de las operaciones de la flota cerquera. Para las predicciones, utilizamos el número promedio de lances totales en cada cuadrante y un tipo de lance al azar para todo el periodo de estudio para detectar si ciertas condiciones ambientales podrían estar favoreciendo la presencia de cuadrantes nulos. Se construyeron mapas mensuales para los meses más representativos de cada trimestre del año (febrero, mayo, agosto y noviembre) para evaluar la variación estacional en la ocurrencia de cuadrantes nulos. Estos mapas deben interpretarse como promedios 


\section{Statistical modeling}

Table 1 summarizes the model selection process. Concurvity for environmental variables was low $(<0.3)$ in all cases. All variables produced a decrease of at least 2 AIC units and were statistically significant at $99 \%$ confidence level (Table 1). The model explained $21.50 \%$ of total deviance. In general, the most important variable was number of sets. The environmental variable with the lowest associated $\triangle \mathrm{AIC}$ and highest cumulative deviance was Chla. On the other hand, ONI was the environmental variable with the highest associated $\triangle \mathrm{AIC}$ and lowest cumulative deviance. Null cells were more likely to occur when SST was between 20 and $24^{\circ} \mathrm{C}$ and higher than $27^{\circ} \mathrm{C}$. A similar situation was observed when Chla concentration was relatively high $\left(>1 \mathrm{mg} \cdot \mathrm{m}^{-3}\right)$, SLA values were positive, ONI values were close to zero, and fishing was done on unassociated tuna schools. Higher probability of occurrence of null cells was observed for the 2007-2012 period and 3 zones: one in the open ocean, around $100^{\circ} \mathrm{W}$ and $20^{\circ} \mathrm{S}$, and two closer to the coast, one at a lower latitude $\left(0-10^{\circ} \mathrm{N}\right)$ and the other in the northern section of the study area $\left(>20^{\circ} \mathrm{N}\right)$ (Fig. 2).

The final model performed well when discriminating absences from presences (AUROC 82.22\%). The seasonal prediction maps showed that the probability of null cell occurrence $(>0.3)$ was higher in an oceanic zone centered at $\sim 20^{\circ} \mathrm{S}, 110^{\circ} \mathrm{W}$ (hereafter oceanic zone), off the coast of Central America (hereafter southern zone), and at the entrance to the Gulf of California (hereafter northern zone). The 3 zones seemed to be present throughout the year, with slight seasonal variations (Fig. 3). The oceanic zone in the southern portion of the study area $\left(\sim 20^{\circ} \mathrm{S}, 110^{\circ} \mathrm{W}\right)$ spatially agrees with a zone where fishing effort was low (cells with $<10$ sets, Fig. 1) during 2003-2015, so this zone was not considered an important tuna fishing area; therefore, the rest of the analysis focused on the other 2 zones for which the model predicted high probability of null cell occurrence (the northern and southern zones).

Low probability of null cell occurrence $(<0.1)$ was observed when the fleet fished using dolphins as fishing indicators (Fig. 4a). Fishing on unassociated tuna schools was the most likely cause for the 2 zones with high probability of null cell occurrence because our model predicted probabilities $>60 \%$ under this scenario (Fig. 4b). Probability of null cell occurrence was relatively high $(\sim 0.2-0.3)$ when simulating that the fleet fished on floating objects (Fig. 4c).

The lowest mean ONI values occurred during 2011 (yearly mean $=-0.72, \mathrm{SD}=0.30$ ) and the highest occurred during 2015 (yearly mean $=1.25, \mathrm{SD}=0.63$ ). The zone with high probability of null cell occurrence near the Central American coast was broader during 2015, when probabilities of null cell occurrence were $>0.6$. The zone with high probability of null cell occurrence at the entrance to the Gulf of California remained practically unchanged when trimestrales de la probabilidad de ocurrencia de cuadrantes nulos para el periodo de agosto de 2003 a diciembre de 2015 . Para resaltar la importancia de cada tipo de indicador de pesca, también simulamos 3 escenarios, como si todos los lances de pesca se hicieran sobre cada uno de los diferentes indicadores de pesca (delfines, cardúmenes de túnidos no asociados o libres y objetos flotantes). Esto resultó en un mapa promedio de la ocurrencia de cuadrantes nulos para todo el periodo de estudio para cada tipo de lance. Además, para representar el posible efecto de los eventos ENOS en la distribución espacial de la ocurrencia de cuadrantes nulos, creamos mapas promedio para 2011 y 2015, cuando los valores promedio del ION fueron más bajos y más altos, respectivamente.

\section{Resultados}

\section{Esfuerzo pesquero}

Durante los primeros 2 trimestres del año, la mayor parte del esfuerzo pesquero de la flota de túnidos con redes de cerco se distribuyó frente a cabo Corrientes, México $\left(\sim 20^{\circ} \mathrm{N}\right.$, $\left.115^{\circ} \mathrm{W}\right)$, donde se observó un parche de $>100$ lances de red de cerco. Se observaron cuadrantes aislados con altos niveles de esfuerzo pesquero ( $>300$ lances) en la parte norte del golfo de Tehuantepec $\left(\sim 15^{\circ} \mathrm{N}, 98^{\circ} \mathrm{W}\right)$ durante el primer trimestre y frente a la costa occidental de la península de Baja California $\left(\sim 24^{\circ} \mathrm{N}, 117^{\circ} \mathrm{W}\right)$ durante el segundo trimestre (Fig. 1a, b). Durante el verano boreal (julio-septiembre) la mayor parte del esfuerzo pesquero se concentró cerca de la península de Baja California (cuadrantes con $>300$ lances) y alrededor del archipiélago de Revillagigedo $\left(\sim 18^{\circ} \mathrm{N}, 115^{\circ} \mathrm{W}\right.$; cuadrantes con $>100$ lances) (Fig. 1c). En el último trimestre del año, el sitio de pesca más importante se observó justo por encima de la línea imaginaria del ecuador, a lo largo de una banda de cuadrantes con 50-100 lances que se extendían desde la costa de Centroamérica hasta $\sim 98^{\circ} \mathrm{W}$ (Fig. 1d).

\section{Modelación estadística}

La tabla 1 resume el proceso de selección del modelo. La concurvidad para las variables ambientales fue baja $(<0.3)$ en todos los casos. Todas las variables produjeron una disminución de al menos 2 unidades CIA y fueron estadísticamente significativas a un nivel de confianza del 99\% (Tabla 1). El modelo explicó el $21.50 \%$ de la variabilidad total. En general, la variable más importante fue el número de lances. La variable ambiental con la $\Delta$ CIA asociada más baja y la variabilidad acumulativa más alta fue Cla. Por otro lado, ION fue la variable ambiental con la $\Delta$ CIA asociada más alta $\mathrm{y}$ la desviación acumulativa más baja. La ocurrencia de los cuadrantes nulos fue más probable cuando la TSM fue de entre 20 y $24{ }^{\circ} \mathrm{C}$ y mayor que $27{ }^{\circ} \mathrm{C}$. Se observó una situación similar cuando la concentración de Cla fue relativamente alta $\left(>1 \mathrm{mg} \cdot \mathrm{m}^{-3}\right)$, los valores de ANM fueron positivos, los valores de ION fueron cercanos a cero y la pesca estuvo 
Table 1. Summary of the logistic generalized additive model fitted to the presence/absence data of null cells for the purse seine fleet in the eastern Pacific Ocean. Abbreviations are sea surface temperature, SST; chlorophyll $a$, Chla; sea level anomaly, SLA; Oceanic Niño Index, ONI; number of sets, NumSets; type of set, SetType; longitude, Lon; latitude, Lat; Akaike information criterion, AIC.

Tabla 1. Resumen del modelo aditivo generalizado logístico ajustado a los datos de presencia/ausencia de cuadrantes nulos para la flota cerquera en el océano Pacífico oriental. Las abreviaturas son la temperatura superficial del mar, SST; la clorofila $a$, Chla; la anomalía del nivel del mar, SLA; el Índice Oceánico de El Niño, ONI; el número de lances, NumSets; el tipo de lance, SetType; la longitud, Lon; la latitud, Lat; el criterio de información de Akaike, AIC.

\begin{tabular}{lcccrc}
\hline & $\begin{array}{c}\text { Explained } \\
\text { deviance }(\%)\end{array}$ & $\begin{array}{c}\text { Cumulative } \\
\text { deviance }(\%)\end{array}$ & AIC & $\Delta$ AIC & P $\left(\chi^{2}\right)$ \\
\hline Null & $0.00 \%$ & $0.00 \%$ & $34,653.76$ & & $<0.01$ \\
+ s(SST) & $1.37 \%$ & $1.37 \%$ & $34,193.49$ & -460.27 & $<0.01$ \\
+ s(log(Chla) & $3.29 \%$ & $1.92 \%$ & $33,541.69$ & -651.80 & $<0.01$ \\
+ s(SLA) & $3.40 \%$ & $0.11 \%$ & $33,512.67$ & -29.02 & $<0.01$ \\
+ s(ONI) & $3.42 \%$ & $0.02 \%$ & $33,505.01$ & -7.66 & $<0.01$ \\
+ s(NumSets) & $11.90 \%$ & $8.48 \%$ & $30,577.53$ & $-2,927.48$ & $<0.01$ \\
+ SetType & $15.10 \%$ & $3.20 \%$ & $29,450.79$ & $-1,126.74$ & $<0.01$ \\
+ s(Month) & $15.20 \%$ & $0.10 \%$ & 29428.56 & -22.23 & $<0.01$ \\
+ s(Year) & $15.50 \%$ & $0.30 \%$ & 29366.95 & -61.61 & $<0.01$ \\
+ s(Lon) & $18.50 \%$ & $3.00 \%$ & 28321.47 & $-1,045.48$ & $<0.01$ \\
+ s(Lat) & $20.10 \%$ & $1.60 \%$ & 27795.53 & -525.94 & $<0.01$ \\
+ s(Lon, Lat) & $21.00 \%$ & $0.90 \%$ & 27494.49 & -301.04 & $<0.01$ \\
+ +s(Lon, Year) & $21.20 \%$ & $0.20 \%$ & 27464.13 & -30.36 & $<0.01$ \\
+ +s(Lat, Year) & $21.50 \%$ & $0.30 \%$ & 27400.44 & -63.69 & $<0.01$ \\
Total & $21.50 \%$ & & & & \\
\hline
\end{tabular}

comparing the spatial distribution of the probability of null cell occurrence during La Niña (2011) and El Niño (2015) conditions (Fig. 5).

\section{Discussion}

\section{Spatiotemporal distribution of fishing effort}

During the first half of the year, increased fishing effort was observed off Cabo Corrientes $\left(\sim 15^{\circ} \mathrm{N}, 110^{\circ} \mathrm{W}\right)$, the entrance to the Gulf of California, Mexico. In this region, intense wind-driven upwelling events occur during the second quarter of the year, with peak primary productivity during the late boreal spring and early summer (López-Sandoval et al. 2009). Moreover, this region is also affected by coastal trapped internal waves, which are capable of generating both cyclonic and anticyclonic eddies when they alter the local poleward currents as they interact with the shape of the coastline (Zamudio et al. 2007). Our results agree with those of Torres-Orozco et al. dirigida a cardúmenes de túnidos no asociados. Se observó una mayor probabilidad de ocurrencia de cuadrantes nulos para el periodo 2007-2012 y en 3 zonas: una en mar abierto, alrededor de $100^{\circ} \mathrm{W}$ y $20^{\circ} \mathrm{S}$, y dos más cercanas a la costa, una en una latitud más baja $\left(0-10^{\circ} \mathrm{N}\right)$ y otra en la sección norte del área de estudio $\left(>20^{\circ} \mathrm{N}\right)$ (Fig. 2).

El modelo final funcionó de manera eficiente al discriminar las ausencias de las presencias (ABCCOR 82.22\%). En los mapas de predicción estacionales se identificó que la probabilidad de ocurrencia de cuadrantes nulos $(>0.3)$ era mayor en una zona oceánica centrada en $\sim 20^{\circ} \mathrm{S}, 110^{\circ} \mathrm{W}$ (en lo sucesivo zona oceánica), frente a la costa de Centroamérica (en lo sucesivo zona sur) y en la entrada al golfo de California (en lo sucesivo zona norte). Las 3 zonas parecieron estar presentes durante todo el año, con ligeras variaciones estacionales (Fig. 3). La zona oceánica en la parte sur del área de estudio $\left(\sim 20^{\circ} \mathrm{S}, 110^{\circ} \mathrm{W}\right)$ coincide espacialmente con una zona donde el esfuerzo pesquero fue bajo (cuadrantes con $<10$ lances, Fig. 1) durante 2003-2015, por lo que esta zona no fue considerada una zona de pesca de túnidos importante; 
(2005), who reported that the number of purse seine sets carried out off Cabo Corrientes by the Mexican tuna fleet increased during March and June. Torres-Orozco et al. (2005) mentioned that this region was an interesting yellowfin tuna fishing ground because water filaments detach from the coastline into the open ocean, as a result of winddriven upwelling events.

During the second half of the year, fishing effort was mostly observed during the boreal summer (JulySeptember) near the Baja California Peninsula, off Mexico $\left(\sim 25^{\circ} \mathrm{N}, 118^{\circ} \mathrm{W}\right)$. The high biological productivity that takes place in this area makes the Baja California Peninsula an important fishing ground for the purse seine fleet. Here wind-driven upwelling events last up to 10 days and are more common during May-June (Cervantes-Duarte et al. 1993, Zaytzev et al. 2003). These upwelling events promote large aggregations of pelagic red crab (Pleuroncodes planipes), one of the favorite prey of the pelagic fish community in the region (Aurioles-Gamboa et al. 1994), por lo tanto, el resto del análisis se centró en las otras 2 zonas para las cuales el modelo predijo una alta probabilidad de ocurrencia de cuadrantes nulos (las zonas norte y sur).

Se observó una baja probabilidad de ocurrencia de cuadrantes nulos $(<0.1)$ cuando la flota pescó utilizando delfines como indicador de pesca (Fig. 4a). La pesca sobre cardúmenes de túnidos no asociados fue la causa más probable de las 2 zonas con alta probabilidad de ocurrencia de cuadrantes nulos porque nuestro modelo pronosticó probabilidades $>60 \%$ para este escenario (Fig. $4 b$ ). La probabilidad de aparición de cuadrantes nulos fue relativamente alta $(\sim 0.2-0.3)$ al simular que la flota pescaba sobre objetos flotantes (Fig. 4c).

Los valores promedio más bajos de ION ocurrieron durante 2011 (media anual $=-0.72, \mathrm{DE}=0.30$ ) y los más altos ocurrieron durante 2015 (media anual $=1.25, \mathrm{DE}=0.63$ ). La zona con alta probabilidad de ocurrencia de cuadrantes nulos cerca de la costa de Centroamérica fue más amplia durante 2015, cuando las probabilidades de ocurrencia de cuadrantes nulos fueron $>0.6$. La zona con alta probabilidad
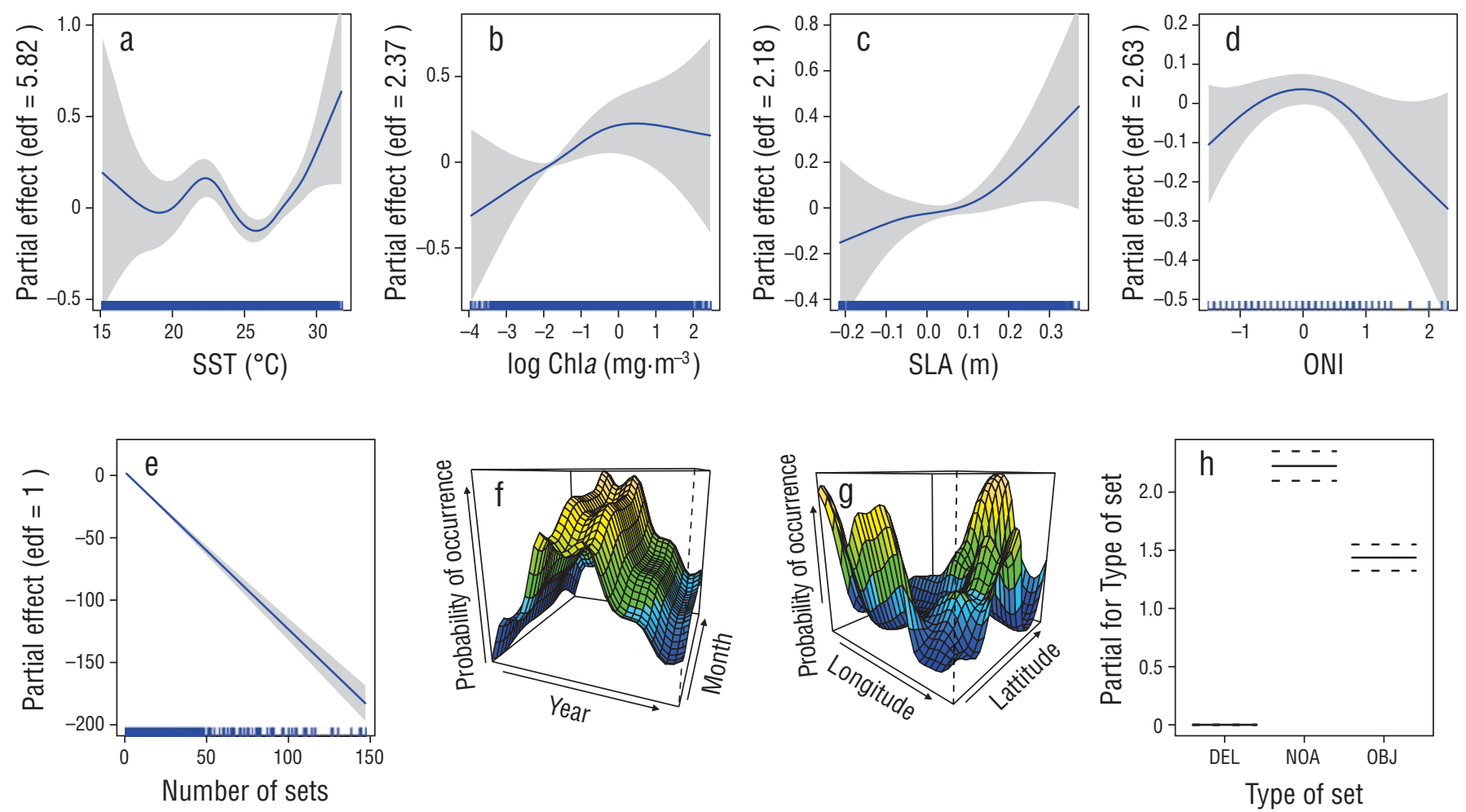

Figure 2. Partial effect plots from the logistic generalized additive model fitted to the fishery and satellite-derived data from August 2003 to December 2015. (a) Sea surface temperature (SST), (b) chlorophyll $a$ (Chla, log-scale), (c) sea level anomaly (SLA), (d) Oceanic Niño Index (ONI), (e) number of sets, (f) month-year interaction, (g) longitude-latitude interaction, and (h) type of set (on dolphins, DEL; unassociated schools, NOA; and floating objects, OBJ). Gray shaded area depicts $95 \%$ confidence intervals, and lines perpendicular to the $x$-axis depict the density of observations for each covariate.

Figura 2. Gráficas de los efectos parciales del modelo aditivo generalizado logístico ajustado a los datos pesqueros y los datos derivados de satélite de agosto de 2003 a diciembre de 2015. (a) Temperatura superficial del mar (SST), (b) clorofila a (Chla, escala logarítmica), (c) anomalía del nivel del mar (SLA), (d) Índice Oceánico de El Niño (ONI), (e) número de lances, (f) interacción mes-año, (g) interacción longitud-latitud y (h) tipo de lance (sobre delfines, DEL; cardúmenes no asociados, NOA; y objetos flotantes, OBJ). El área en gris representa intervalos de confianza del 95\%, y las líneas perpendiculares al eje $x$ representan la densidad de observaciones para cada covariable. 


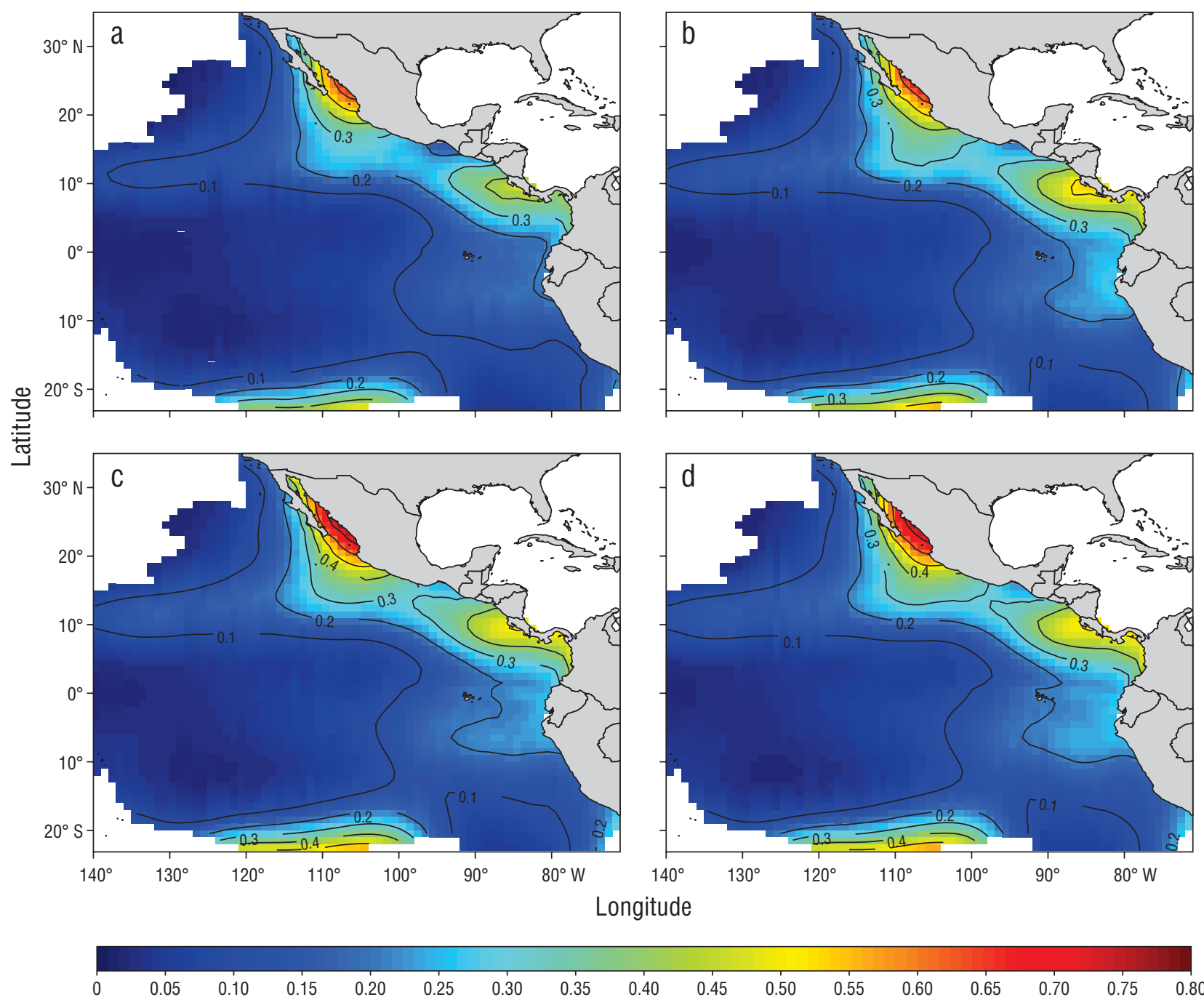

Figure 3. Mean quarterly spatial prediction of the probability of occurrence of null cells for the period from August 2003 to December 2015. Predictions are made for the first (January-March) (a), second (April-June), third (July-September), and fourth (October-December) quarters of the year. Color bar depicts the probability of occurrence of null cells. Contours are printed in 0.1 increments.

Figura 3. Predicción espacial trimestral promedio de la probabilidad de ocurrencia de cuadrantes nulos para el periodo de agosto de 2003 a diciembre de 2015. Se hacen predicciones para el primer (enero-marzo) (a), segundo (abril-junio) (b), tercero (julio-septiembre) (c) y cuarto (octubre - diciembre) (d) trimestre del año. La barra de colores representa la probabilidad de ocurrencia de cuadrantes nulos. Los contornos muestran incrementos de 0.1 .

including yellowfin tuna (Bocanegra-Castillo 2007). Ortega-García and Lluch-Cota (1996) found a 3-month lag between peak upwelling intensity and peak yellowfin catch rates in Pacific waters off southern Mexico and attributed this lag to the time required for predators higher in the food chain to arrive at an upwelling area. Therefore, during JulySeptember, 2 to 3 months after the peak upwelling activity in the region, yellowfin, the main target species of the purse seine fleet that operates in the ETPO (Maunder and Watters 2003), arrives in the area near the Baja California Peninsula to feed on pelagic red crab, explaining the increased fishing effort observed during the boreal summer. de ocurrencia de cuadrantes nulos en la entrada al golfo de California se mantuvo prácticamente sin cambios al comparar la distribución espacial de la probabilidad de ocurrencia de cuadrantes nulos durante las condiciones de La Niña (2011) y El Niño (2015) (Fig. 5).

\section{Discusión}

\section{Distribución espaciotemporal del esfuerzo pesquero}

Durante la primera mitad del año, se observó un mayor esfuerzo pesquero frente a cabo Corrientes $\left(\sim 15^{\circ} \mathrm{N}, 110^{\circ} \mathrm{W}\right)$, 


\section{Modeling and spatial prediction of the probability of occurrence of null cells}

In general, operational variables were more important in explaining the probability of null cell occurrence, compared with environmental variables. For example, the variable that accounted for most of the explained deviance was number of sets, with higher probability of null cell occurrence at low numbers of purse seine sets. This suggests that the probability of a null cell occurring decreased when fisher insistency increased. Fishing indicator (type of set) was the variable that followed in importance. Increased probability of la entrada al golfo de California, México. En esta región, se producen eventos de surgencia intensos inducidos por el viento durante el segundo trimestre del año, con un pico de productividad primaria durante finales de la primavera boreal y principios de verano (López-Sandoval et al. 2009). Además, esta región también es afectada por las ondas internas atrapadas en la costa, las cuales son capaces de generar remolinos ciclónicos y anticiclónicos al alterar las corrientes locales que fluyen hacia los polos cuando interactúan con la forma de la línea de costa (Zamudio et al. 2007). Nuestros resultados concuerdan con los de Torres-Orozco et al. (2005), quienes reportaron que el número de lances de red de cerco realizados
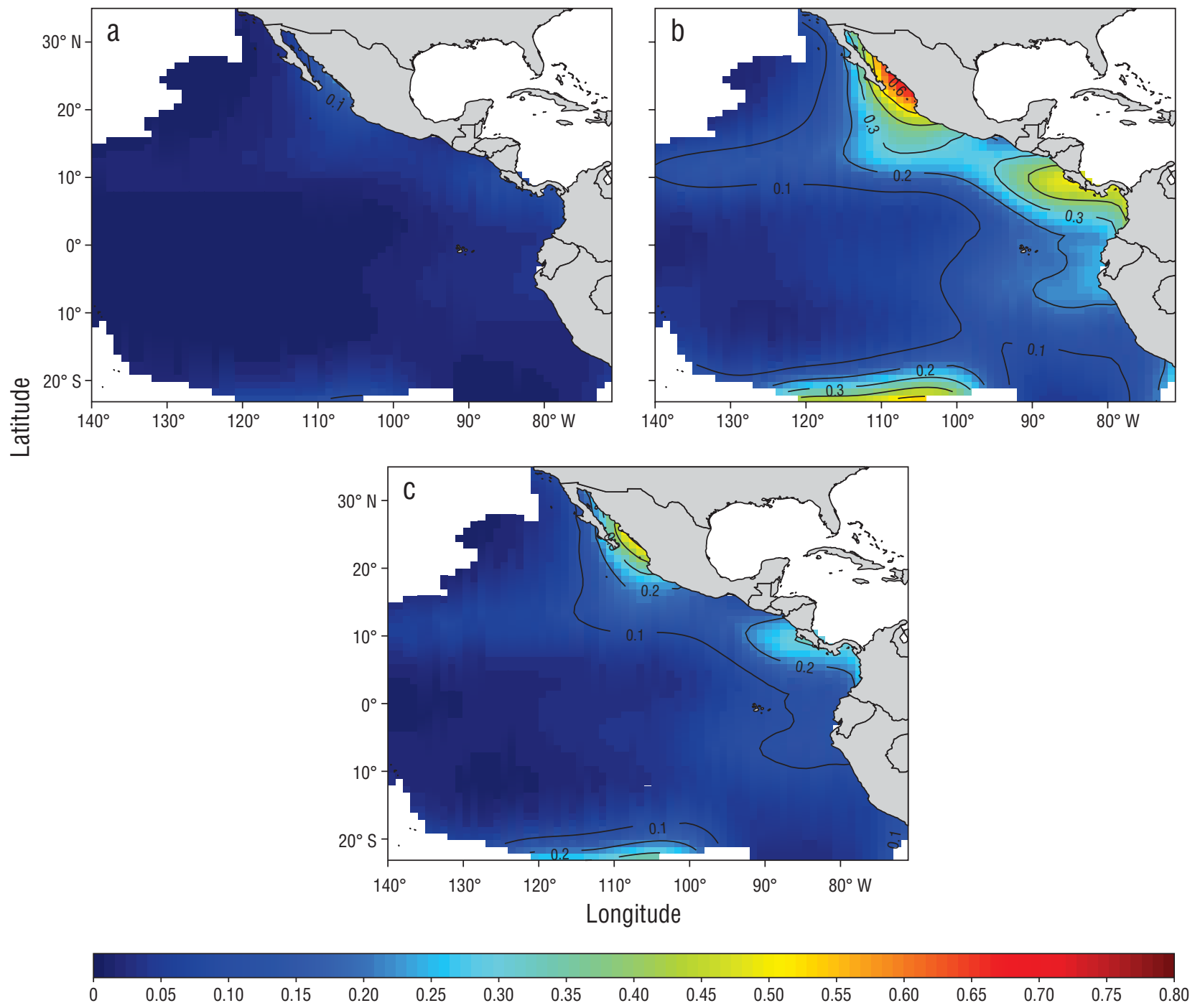

Figure 4. Mean maps for the prediction of null cell occurrence in the period from August 2003 to December 2015 under different simulation scenarios. Simulations were made assuming all the purse seine sets were made on dolphins (a), unassociated (free-swimming) tuna schools (b), and floating objects (c). Color bar depicts the probability of occurrence of null cells. Contours are printed in 0.1 increments.

Figura 4. Mapas promedio para la predicción de la ocurrencia de cuadrantes nulos para el periodo de agosto de 2003 a diciembre de 2015 bajo diferentes escenarios de simulación. Las simulaciones se realizaron suponiendo que todos los lances cerqueros se realizaban sobre delfines (a), cardúmenes de túnidos no asociados (libres) (b) y objetos flotantes (c). La barra de colores representa la probabilidad de ocurrencia de cuadrantes nulos. Los contornos muestran incrementos de 0.1 . 

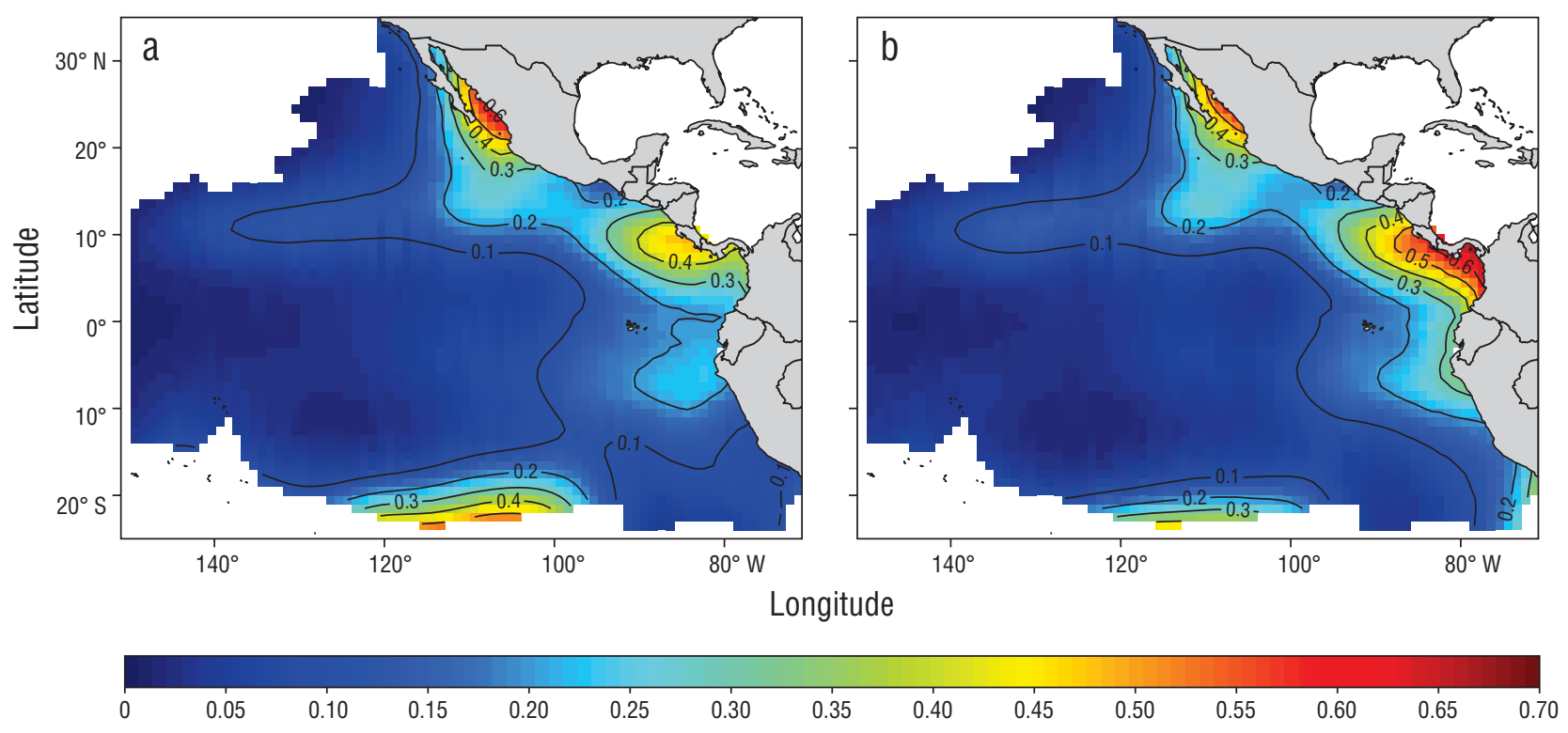

Figure 5. Mean yearly predictions of null cell probability of occurrence for those years with extreme Oceanic Niño Index (ONI) values in the period from August 2003 to December 2015: (a) 2011 (lowest values) and (b) 2015 (highest values). Color bar depicts the probability of occurrence of null cells. Contours are printed in 0.1 increments.

Figura 5. Predicciones anuales promedio de la probabilidad de ocurrencia de cuadrantes nulos para aquellos años con valores extremos del Índice Oceánico de El Niño (ION) en el periodo de agosto de 2003 a diciembre de 2015: (a) 2011 (valores más bajos) y (b) 2015 (valores más altos). La barra de colores representa la probabilidad de ocurrencia de cuadrantes nulos. Los contornos muestran incrementos de 0.1 .

null cell occurrence was observed when purse seiners fished on unassociated (free-swimming) tuna schools. This result is consistent with previous reports for the Indian, Atlantic, and Pacific oceans (Fonteneau et al. 2000, Delgado De Molina et al. 2010, Floch et al. 2012), and it appears to be attributable to the fact that medium-sized tunas $(10-15 \mathrm{~kg})$, the most common size in free-swimming schools, are more evasive and therefore more difficult to catch in purse seine maneuvers (Fonteneau et al. 2000, Hallier and Gaertner 2008).

Of the environmental variables, surface Chla concentration was the most important covariate, and higher probabilities of null cell occurrence were observed at relatively high Chla values. One plausible explanation for this is that small- and medium-sized tunas, which occupy lower positions in the food web than their larger relatives, inhabit areas with higher Chla concentrations, feeding on small prey that are closer to the lower trophic levels occupied by phytoplankton containing Chla (Ménard et al. 2006). Moreover, Brill and Lutcavage (2001) found that small juvenile bluefin tuna prefer zones with relatively high Chla concentrations. Since medium-sized tunas are more elusive than larger tunas (Fonteneau et al. 2000), the probability of null cell occurrence is expected to be higher in Chla-rich zones, where small- and medium-sized tunas are likely to inhabit.

Our final model predicted high probabilities of null cell occurrence in 2 zones that are environmentally different. Ocean dynamics in the southern zone are dominated by the frente a cabo Corrientes por la flota de túnidos mexicana aumentó durante marzo y junio. Torres-Orozco et al. (2005) señalaron que esta región era un sitio de pesca de atún aleta amarilla interesante porque filamentos de agua se separan de la costa hacia mar abierto, como resultado de los eventos de surgencia inducidos por el viento.

Durante la segunda mitad del año, el esfuerzo pesquero se observó principalmente durante el verano boreal (julioseptiembre) cerca de la península de Baja California, frente a México $\left(\sim 25^{\circ} \mathrm{N}, 118^{\circ} \mathrm{W}\right)$. La alta productividad biológica que presenta esta área hace que la península de Baja California sea un sitio de pesca importante para la flota cerquera. Aquí, los eventos de surgencia inducidos por el viento duran hasta 10 días y son más comunes durante mayo-junio (Cervantes-Duarte et al. 1993, Zaytzev et al. 2003). Estos eventos de surgencia promueven grandes agregaciones de langostilla roja (Pleuroncodes planipes), una de las presas favoritas de la comunidad de peces pelágicos en la región (Aurioles-Gamboa et al. 1994), incluido el atún aleta amarilla (Bocanegra-Castillo 2007). Ortega-García y Lluch-Cota (1996) encontraron un retraso de 3 meses entre la intensidad máxima de los eventos de surgencia y las tasas máximas de captura de atún aleta amarilla en las aguas del Pacífico frente al sur de México y atribuyeron este retraso al tiempo requerido para que los depredadores más altos en la cadena alimentaria lleguen a una zona de surgencia. Por lo tanto, durante julio-septiembre, 2 a 
North Equatorial Current, the Costa Rica Dome, and the Papagayo and Panamá wind jets. Mean SST values in this zone are $>26^{\circ} \mathrm{C}$, with very little seasonal variations $\left( \pm 2{ }^{\circ} \mathrm{C}\right.$, Fiedler and Talley 2006). The thermocline in this zone is mostly shallow $(<50 \mathrm{~m})$ all year long (Fiedler 2002). The northern zone, on the other hand, lies in the transition zone where the cold, nutrient-rich waters from the California Current meet the warm and oligotrophic water masses of equatorial origin (Kessler 2006). Sharp seasonal variations in SST occur in this zone, with values of $20-24{ }^{\circ} \mathrm{C}$ during the first quarter and $>28{ }^{\circ} \mathrm{C}$ during the third quarter. The thermocline in this zone is usually found at shallow depths $(<60 \mathrm{~m})$, although seasonal variations in thermocline depth are more evident here than in the southern zone, and it is shallower during the second quarter of the year (Fiedler and Talley 2006).

Dreyfus-León et al. (2015) suggested that the main cause of zero-catch sets in the northern zone is the seasonal deepening of the thermocline, because tunas are able to escape through the bottom of the purse seine. Dreyfus-León et al. (2015) used a basic statistics technique (linear correlation) to highlight the relationship between null sets and environmental variables (the Multivariate El-Niño Index). We believe that our results are more robust because (1) the spatiotemporal coverage of our data is broader, (2) we used additional environmental variables (SST, Chla, SLA, ONI) as predictors, and (3) we applied an improved statistical technique to analyze nonlinear relationships between predictors and the logit of null cell occurrence. Environmental variables, including the variable that causes the deepening of the thermocline (ONI) and the one that can be used as a proxy for thermocline depth (SLA), explained only a small percentage of total deviance, as opposed to operational variables. Moreover, most of the purse seine sets made on unassociated tuna schools were carried out in the 2 zones (near the Baja California Peninsula and near the Central American coast) for which our model predicted higher probabilities of null cell occurrence (Fig. S1). Therefore, operational factors seem to be more important for the occurrence of null cells than variations in the marine environment.

\section{Economic and ecological impact of predicting areas with high probability of null cell occurrence}

The final GAM quantifies the probability of occurrence of null cells for the tuna purse seine fishery operating in the EPO. The model could be used as a decision-making tool by crews in purse seine tuna vessels that operate in the EPO. For example, of the Ecuadorian purse seine fleet (Bucaram 2017), if we presume that a purse seiner performs half (13) of the yearly mean sets (26) in a fishing trip to one of the zones where the probability of null cells is $\sim 30 \%$, then $13 \times 0.3 \sim 4$ of those cells would be a zero-catch set. On the other hand, if the crew of this purse seiner decides to carry out these 13 sets in a zone where the probability of
3 meses después de la actividad máxima de surgencia en la región, el atún aleta amarilla, la principal especie a la que se dirige la flota cerquera que opera en el OPTO (Maunder y Watters 2003), llega al área adyacente a la península de Baja California para alimentarse de langostilla roja, lo cual explica el mayor esfuerzo pesquero observado durante el verano boreal.

\section{Modelación y predicción espacial de la probabilidad de ocurrencia de cuadrantes nulos}

En general, las variables operacionales fueron más importantes para explicar la probabilidad de ocurrencia de cuadrantes nulos, en comparación con las variables ambientales. Por ejemplo, la variable que representó la mayor parte de la desviación explicada fue el número de lances, con una mayor probabilidad de ocurrencia de cuadrantes nulos a un número bajo de lances de red de cerco. Esto sugiere que la probabilidad de que ocurriera un cuadrante nulo disminuyó cuando aumentó la insistencia de los pescadores. El indicador de pesca (tipo de lance) fue la variable que siguió en importancia. Se observó una mayor probabilidad de ocurrencia de cuadrantes nulos cuando la flota cerquera se dirigió a cardúmenes de túnidos no asociados (libres). Este resultado es consistente con lo reportado anteriormente para los océanos Índico, Atlántico y Pacífico (Fonteneau et al. 2000, Delgado De Molina et al. 2010, Floch et al. 2012), y parece que esto se atribuye a que los atunes de tamaño mediano (10-15 kg), el tamaño más común en los cardúmenes libres, son más evasivos y, por lo tanto, más difíciles de atrapar con las maniobras de las redes de cerco (Fonteneau et al. 2000, Hallier y Gaertner 2008).

De las variables ambientales, la concentración de Cla superficial fue la covariable más importante, y se observaron mayores probabilidades de ocurrencia de cuadrantes nulos con valores de Cla relativamente altos. Una explicación plausible para esto es que los atunes pequeños y medianos, que ocupan posiciones más bajas en la red alimentaria que sus parientes más grandes, habitan áreas con concentraciones de Cla más altas, alimentándose de presas pequeñas que están más cerca de los niveles tróficos más bajos ocupados por el fitoplancton que contiene Cla (Ménard et al. 2006). Además, Brill y Lutcavage (2001) encontraron que los juveniles de atún aleta azul pequeños prefieren zonas con concentraciones de Cla relativamente altas. Dado que los atunes medianos son más elusivos que los atunes más grandes (Fonteneau et al. 2000), se espera que la probabilidad de que ocurran cuadrantes nulos sea mayor en las zonas ricas en Cla, donde es probable que habiten atunes pequeños y medianos.

Nuestro modelo final predijo altas probabilidades de ocurrencia de cuadrantes nulos en 2 zonas que son ambientalmente diferentes. La dinámica oceánica en la zona sur está dominada por la corriente Ecuatorial del Norte, el Domo de Costa Rica y los chorros de viento de Papagayo 
occurrence of null cells is $\sim 10 \%$ (or to fish using a fishing indicator other than unassociated tuna schools), then only around $13 \times 0.1 \sim 1.3$ of the 13 sets would be unproductive, thus saving $4,120 \times 3 \sim 12,360$ USD (where 3 is the difference of unproductive sets in both theoretical scenarios) of the mean cost of the fishing trip.

Minimizing the fishing effort by the purse seine fleet could also have interesting ecological consequences. For example, for purse seiners with storage capacity $>452 \mathrm{~m}^{3}$, Marín-Enríquez et al. (2018) reported a mean bycatch of $\sim 55$ dolphinfish (Coryphaena spp.) per purse seine set in the EPO during 2004-2013, and Cruz-Cosío (2018) estimated a mean bycatch of up to 0.7 individuals of the critically endangered oceanic whitetip shark (Carcharhinus longimanus) per set during 1993-2005. For the same 2 theoretical scenarios described above, the difference of 3 unproductive sets would imply a bycatch decrease of $55 \times 3 \times 6 \sim 990$ dolphinfish per year per vessel and of $0.7 \times 3 \times 6 \sim 13$ individuals of oceanic whitetip shark per year per vessel ( 3 sets per trip, 6 trips per year). Of course, these are mean rough estimates, and even though they are based on assumptions that could not be entirely true, they could give the reader an insight into the advantage of decreasing the fishing effort by the purse seine fleet in the EPO, from the marine conservation perspective.

\section{ACKNOWLEDGMENTS}

We are thankful to the IATTC for providing the fishery database used in this paper, especially to Nick Vogel, who provided valuable help for better understanding the database. EME thanks the National Council of Science and Technology (CONACYT, Mexico) for their support through the "Cátedras" program (project no. 2137). XGMS is grateful for support received through COFAA-IPN and EDI-IPN. EME and XGMS thank CONACYT for support through the Sistema Nacional de Investigadores (National System of Researchers, Mexico). We thank the 3 anonymous reviewers, who helped improve the quality of our manuscript. The authors declare no conflict of interest.

\section{REFERENCES}

Aurioles-Gamboa D, Castro-González MI, Pérez-Flores R. 1994. Annual mass strandings of pelagic red crabs, Pleuroncodes planipes (Crustacea: Anomura: Galatheidae), in Bahia Magdalena, Baja California Sur, Mexico. Fish Bull. 92:464-470.

AVISO+ Satellite Altimetry Data. 1993-2020. MSLA-Monthly mean and climatology maps of Sea Level Anomalies. Ramonville (France): AVISO+. [updated 2020 Jan 15; accessed 2016 Jul 18]. https://www.aviso.altimetry.fr/index.php?id=1526.

Badán A. 1997. La Corriente Costera de Costa Rica en el Pacífico Mexicano. In: Lavín MF (ed.), Contribuciones a la Oceanografía Física en México. Monografía 3. Ensenada (Mexico): Unión Geofísica Mexicana. p. 99-112. y Panamá. Los valores promedio de la TSM en esta zona son $>26^{\circ} \mathrm{C}$, con muy pocas variaciones estacionales $\left( \pm 2{ }^{\circ} \mathrm{C}\right.$, Fiedler y Talley 2006). La termoclina en esta zona es mayormente somera $(<50 \mathrm{~m})$ durante todo el año (Fiedler 2002). La zona norte, por otro lado, se encuentra en la zona de transición donde las aguas frías y ricas en nutrientes de la corriente de California confluyen con las masas de agua cálidas y oligotróficas provenientes del ecuador (Kessler 2006). En esta zona se producen fuertes variaciones estacionales en la TSM, con valores de $20-24{ }^{\circ} \mathrm{C}$ durante el primer trimestre y $>28^{\circ} \mathrm{C}$ durante el tercer trimestre. La termoclina en esta zona generalmente se encuentra a poca profundidad $(<60 \mathrm{~m})$, aunque las variaciones estacionales en la profundidad de la termoclina son más evidentes aquí que en la zona sur, y es menos profunda durante el segundo trimestre del año (Fiedler y Talley 2006).

Dreyfus-León et al. (2015) sugirieron que la causa principal de los lances con captura nula en la zona norte es la profundización estacional de la termoclina porque los atunes pueden escapar por el fondo de la red de cerco. Dreyfus-León et al. (2015) utilizaron una técnica estadística básica (correlación lineal) para resaltar la relación entre los lances nulos y las variables ambientales (el índice multivariado de El Niño). Creemos que nuestros resultados son más robustos porque (1) la cobertura espaciotemporal de nuestros datos es más amplia, (2) utilizamos variables ambientales adicionales (TSM, Cla, ANM, ION) como predictores y (3) aplicamos una técnica estadística mejorada para analizar las relaciones no lineales entre predictores y el logit de la ocurrencia de cuadrantes nulos. Las variables ambientales, incluyendo la variable que causa la profundización de la termoclina (ION) y la que se puede usar como indicador de la profundidad de la termoclina (ANM), explicaron solo un pequeño porcentaje de la desviación total, a diferencia de las variables operativas. Además, la mayoría de los lances de redes de cerco realizados sobre cardúmenes de túnidos no asociados se realizaron en las 2 zonas (cerca de la península de Baja California y cerca de la costa de Centroamérica) para las cuales nuestro modelo predijo mayores probabilidades de ocurrencia de cuadrantes nulos (Fig. S1). Por lo tanto, los factores operativos parecen ser más importantes para la ocurrencia de cuadrantes nulos que las variaciones en el entorno marino.

\section{Impacto económico y ecológico de la predicción de áreas con alta probabilidad de ocurrencia de cuadrantes nulos}

El MAG final cuantifica la probabilidad de ocurrencia de cuadrantes nulos para la pesquería de túnidos que opera con redes de cerco en el OPO. El modelo podría ser utilizado como una herramienta para la toma de decisiones por parte de las tripulaciones de las embarcaciones de túnidos que operan con redes de cerco en el OPO. Por ejemplo, de la flota cerquera de Ecuador (Bucaram 2017), si suponemos 
Bigelow KA, Hampton J, Miyabe N. 2002. Application of a habitatbased model to estimate the effective longline fishing effort and relative abundance of Pacific bigeye tuna (Thunnus obesus). Fish Oceanogr. 11(3):143-155.

https://doi.org/10.1046/j.1365-2419.2002.00196.x

Brill RW. 1994. A review of temperature and oxygen tolerance studies of tunas pertinent to fisheries oceanography, movement models and stock assessments. Fish Oceangr. 3(3):204-216. https://doi.org/10.1111/j.1365-2419.1994.tb00098.x

Brill RW, Lutcavage ME. 2001. Understanding environmental influences on movements and depth distributions of tunas and billfishes can significantly improve population assessments. Am Fish Soc Symp. 25:179-198.

Bocanegra-Castillo N. 2007. Relaciones tróficas de los peces pelágicos asociados a la pesquería de atún en el Océano Pacífico Oriental [dissertation]. $\mathrm{La} \mathrm{Paz}$ (Mexico): Centro Interdisciplinario de Ciencias Marinas del Instituto Politécnico Nacional. 178 p.

Bucaram SJ. 2017. Cost benefit and financial analyses of quota managed options for bigeye and yellowfin tunas in the eastern Pacific Ocean. Rome: Food and Agriculture Organization of the United Nations. World Wildlife Fund. 87 p. Final report for the World Wildlife Fund Inc.

Burnham KP, Anderson DR. 2002. Model Selection and Multimodel Inference: A Practical Information-Theoretic Approach. 2nd ed. Berlin (Germany): Springer-Verlag. 488 p.

Cervantes-Duarte R, Aguíñiga-García S, Hernández-Trujillo S. 1993. Condiciones de surgencia asociadas a la distribución de zooplankton en San Hipólito, B.C.S. = Upwelling conditions associated to the distribution of zooplancton in San Hipolito, B.C.S. Cienc Mar. 19(1):117-135. http://dx.doi.org/10.7773/cm.v19i1.917

Chassot E, Delgado De Molina A, Assan C, Dewals P, Cauquil P, Aresso JJ, Rahombanjanahary DM, Floch L. 2013. Statistics of the European Union and associated flags purse seine fishing fleet targeting tropical tunas in the Indian Ocean 1981-2012. Victoria (Seychelles): Indian Ocean Tuna Commission. IOTC2013WPTT15-44.

Cruz-Cosío R. 2018. Variación espacio-temporal de la captura incidental de tiburones pelágicos en el Océano Pacífico oriental tropical, y su relación con factores oceanográficos [MSc thesis]. La Paz (Mexico): Centro Interdisciplinario de Ciencias Marinas del Instituto Politécnico Nacional. 96 p.

Delgado De Molina A, Aresso JJ, Ariz J. 2010. Statistics of the purse seine Spanish fleet in the Indian Ocean (1984-2009). Victoria (Seychelles): Indian Ocean Tuna Commission. $21 \mathrm{p}$. IOTC-2010-WPTT-19.

Dreyfus-León MJ, Mejía A. 2009. Lances de agua. El Vigía. 35:34. https://www.fidemar.org/revista-el-vigia

Dreyfus-León MJ, Mejía-Trejo A, Villaseñor-Derbez JC. 2015. Analysis of null sets (zero catch) made by the Mexican tuna purse seine fleet (2000-2013) = Análisis de los lances nulos (sin captura) de la flota atunera mexicana que opera con red de cerco (2000-2013). Cienc Mar. 41(2): 85-92. https://doi.org/10.7773/cm.v41i2.2471

ERDDAP. 2003-2016. SST, POES AVHRR, GAC, Global, Day and Night, 2003-2016 (Monthly Composite). Washington (D.C.): National Oceanic and Atmospheric Administration (US), National Marine Fisheries Service, Southwest Fisheries Science Center, Environmental Research Division. [updated 2016 Mar 5; accessed 2016 Dec 5]. Dataset ID: erdAGsstamday; https:// coastwatch.pfeg.noaa.gov/erddap/griddap/erdAGsstamday. graph. que una embarcación cerquera realiza la mitad (13) de los lances promedio anuales (26) en una campaña de pesca a una de las zonas donde la probabilidad de cuadrantes nulos es $\sim 30 \%$, entonces $13 \times 0.3 \sim 4$ de esos cuadrantes serían un lance de captura nula. Por otro lado, si la tripulación de esta embarcación cerquera decide realizar estos 13 lances en una zona donde la probabilidad de ocurrencia de cuadrantes nulos es de $\sim 10 \%$ (o pescar usando un indicador de pesca que no sea cardúmenes de túnidos no asociados), entonces solo alrededor de $13 \times 0.1 \sim 1.3$ de los 13 lances serían improductivos, ahorrando así 4,120 × $3 \sim 12,360$ dólares (donde 3 es la diferencia de lances improductivos en ambos escenarios teóricos) del costo promedio de la campaña de pesca.

Minimizar el esfuerzo pesquero de la flota cerquera también podría tener consecuencias ecológicas interesantes. Por ejemplo, para embarcaciones cerqueras con capacidad de bodega $>452 \mathrm{~m}^{3}$, Marín-Enríquez et al. (2018) reportaron una captura incidental promedio de $\sim 55$ dorados (Coryphaena spp.) por lance de red de cerco en el OPO durante 2004-2013, y Cruz-Cosío (2018) estimó una captura incidental promedio de hasta 0.7 individuos de tiburón oceánico de puntas blancas (Carcharhinus longimanus), especie en peligro crítico de extinción, por lance durante 1993-2005. Para los mismos 2 escenarios teóricos descritos anteriormente, la diferencia de 3 lances improductivos implicaría una disminución de la captura incidental de $55 \times 3 \times 6 \sim 990$ dorados por año por embarcación y de $0.7 \times 3 \times 6 \sim 13$ individuos de tiburón oceánico de puntas blancas por año por embarcación (3 lances por campaña, 6 campañas por año). Por supuesto, estas son estimaciones aproximadas, y aunque se basan en suposiciones que podrían no ser del todo ciertas, podrían proporcionar al lector una visión de la ventaja de disminuir el esfuerzo pesquero de la flota que opera con red de cerco en el OPO, desde la perspectiva de la conservación marina.

\section{Agradecimientos}

Agradecemos a la CIAT por proporcionar la base de datos pesqueros utilizada en este trabajo, en especial a Nick Vogel, quien proporcionó ayuda valiosa para comprender mejor la base de datos. EME agradece al Consejo Nacional de Ciencia y Tecnología (CONACYT, México) por su apoyo a través del programa "Cátedras" (proyecto no. 2137). XGMS agradece el apoyo recibido a través de COFAA-IPN y EDI-IPN. EME y XGMS agradecen a CONACYT por su apoyo a través del Sistema Nacional de Investigadores (México). Agradecemos a los 3 revisores anónimos, quienes ayudaron a mejorar la calidad de nuestro manuscrito. Los autores declaran no tener ningún conflicto de intereses.

Traducido al español por Claudia Michel-Villalobos. 
ERDDAP. 2003-2020. Chlorophyll-a, Aqua MODIS, NPP, L3SMI, Global, 4km, Science Quality, 2003-present (Monthly Composite). Version 2018.0QL. Washington (D.C.): National Aeronautics and Space Administration (US). [updated $2020 \mathrm{Feb}$ 17; accessed 2017 Jul 7]. Dataset ID: erdMH1chlamday; https:// coastwatch.pfeg.noaa.gov/erddap/griddap/erdMH1chlamday. graph.

Farrell ER, Boustany AM, Halpin PN, Hammond DL. 2014. Dolphinfish (Coryphaena hippurus) distribution in relation to biophysical ocean conditions in the northwest Atlantic. Fish Res. 151:177-190. https://doi.org/10.1016/j.fishres.2013.11.014

Fiedler PC. 2002. The annual cycle and biological effects of the Costa Rica dome. Deep Sea Res Part I. 49(2):321-338. https://doi.org/10.1016/S0967-0637(01)00057-7

Fiedler PC, Talley LD. 2006. Hydrography of the eastern tropical Pacific: a review. Progr Oceanogr. 69(2-4):143-180. https://doi.org/10.1016/j.pocean.2006.03.008

Floch L, Chassot E, Damiano A, Fonteneau V, Kouassi Y, Cauquil P, Amandé MJ, Pianet R, Chavance P. 2012. Statistics of the French purse seine fleet targeting tropical tunas in the Atlantic Ocean (1991-2010). Collect. Vol. Sci. Pap. ICCAT. 68(3):58-885.

Fonteneau A, Lucas V, Tewkai E, Delgado A, Demarcq H. 2008. Mesoscale exploitation of a major tuna concentration in the Indian Ocean $=$ Exploitation à méso-échelle d'une concentration de thons dans l'océan Indien. Aquat Living Resour. 21(2):109-121. https://doi.org/10.1051/alr:2008028

Fonteneau A, Pallarès P, Pianet R. 2000. A worldwide review of purse seine fisheries on FADs. In: Le Gall JY, Cayré P, Taquet $M$ (eds.), Pêche thonière et dispositifs de concentration de poissons; 1999 Oct 15-19, Martinique, Lesser Antilles. Actes Colloques-Ifremer. 28:15-35 p.

Guillotreau P, Saladarré F, Dewals P, Dagorn L. 2011. Fishing tuna around Fish Aggregating Devices (FADs) vs free swimming schools: Skipper decision and other determining factors. Fish Res. 109(2-3):234-242.

https://doi.org/10.1016/j.fishres.2011.02.007

Hallier JP, Gaertner D. 2008. Drifting fish aggregation devices could act as an ecological trap for tropical tuna species. Mar Ecol Prog Ser. 353:255-264. https://doi.org/10.3354/meps07180

[IATTC] Inter-American Tropical Tuna Commission. 2004. Workshop on developing indices of abundance from purseseine catch and effort data; 2004 November 3-4, La Jolla (CA). [place unknown]: IATTC. $13 \mathrm{p}$.

[IATTC] Inter-American Tropical Tuna Commission. 2017. Tunas, billfishes and other pelagic species in the eastern Pacific Ocean in 2016. Fishery status report. [place unknown]: IATTC. $191 \mathrm{p}$.

Itoh T, Tsuji S, Nitta A. 2003. Migration patterns of young Pacific bluefin tuna (Thunnus orientalis) determined with archival tags. Fish Bull. 101(3):514-534.

Jimenez-Tello P. 2014. Efecto de la variabilidad ambiental en la distribución espacio-temporal de cardúmenes no asociados de atún aleta amarilla (Thunnus albacares) en el Noroeste de México [MSc thesis]. La Paz (Mexico): Centro Interdisciplinario de Ciencias Marinas del Instituto Politécnico Nacional. 77 p.

Kessler WS. 2006. The circulation of the eastern tropical Pacific: A review. Progr Oceanogr. 69(2-4):181-217. https://doi.org/10.1016/j.pocean.2006.03.009

López-Sandoval DC, Lara-Lara JR, Lavín MF, Álvarez-Borrego S, Gaxiola-Castro G. 2009. Primary productivity in the eastern tropical Pacific off Cabo Corrientes, Mexico = Productividad primaria en el Pacífico oriental tropical adyacente a Cabo Corrientes, México. Cienc Mar. 35(2):169-182.

https://dx.doi.org/10.7773/cm.v35i2.1530

McPhaden MJ. 1999. Genesis and evolution of the 1997-98 El Niño. Science. 283(5404):950-954.

https://doi.org/10.1126/science.283.5404.950

Marín-Enríquez E, Seoane J, Muhlia-Melo A. 2018. Environmental modeling of occurrence of dolphinfish (Coryphaena spp.) in the Pacific Ocean off Mexico reveals seasonality in abundance, hot spots and migration patterns. Fish Oceanogr. 27(1):28-40.

https://doi.org/10.1111/fog.12231

Martínez-Rincón RO, Ortega-García S, Vaca-Rodríguez JG. 2012. Comparative performance of generalized additive models and boosted regression trees for statistical modeling of incidental catch of wahoo (Acanthocybium solandri) in the Mexican purse-seine tuna fishery. Ecol Modell. 233:20-25.

https://doi.org/10.1016/j.ecolmodel.2012.03.006

Maunder MN, Watters GM. 2003. A-SCALA: An Age-Structured Statistical Catch-At-Length Analysis for Assessing Tuna Stocks in the Eastern Pacific Ocean. Bull Inter-Am Trop Tuna Comm. 22(5):435-582.

McCluney JK, Anderson CM, Anderson JL. 2019. The fishery performance indicators for global tuna fisheries. Nat Commun. 10:1641. https://doi.org/10.1038/s41467-019-09466-6

Ménard F, Labrune C, Shin YJ, Asine AS, Bard FX. 2006. Opportunistic predation in tuna: a size-based approach. Mar Ecol Prog Ser. 323:223-231. https://doi.org/10.3354/meps323223

Miyake MP, Miyabe N, Nakano H. 2004. Historical trends of tuna catches in the world. FAO Fisheries Technical Paper. Rome (Italy): Food and Agriculture Organization of the United Nations. 74 p. PaperNo.: 467. http://www.fao.org/3/y5428e/ y5428e00.htm\#Contents

Mugo R, Saitoh SI, Nihira A, Kuroyama T. 2010. Habitat characteristics of skipjack tuna (Katsuwonus pelamis) in the western North Pacific: a remote sensing perspective. Fish Ocean. 19(5):382-396.

https://doi.org/10.1111/j.1365-2419.2010.00552.x

Ortega-García S, Lluch-Cota S. 1996. Distribución de la abundancia del atún aleta amarilla (Thunnus albacares) y su relación con la concentración de pigmentos fotosintéticos medidos por satélite en aguas al sur de México. Invest Geogr. 4:85-93.

Pecoraro C, Babbucci M, Franch R, Rico C, Papetti C, Chassot E, Bodin N, Cariani A, Bargelloni L, Tinti F. 2018. The population genomics of yellowfin tuna (Thunnus albacares) at global geographic scale challenges current stock delineation. Sci Rep. $8: 13890$ https://doi.org/10.1038/s41598-018-32331-3

PublicPSTunaSetType. 1958-2016. La Jolla (CA): Inter-American Tropical Tuna Commission. [updated 2019 May; accessed 2017 May 5]. https://www.iattc.org/PublicDomainData/IATTCCatch-by-species1.htm.

R Core Team. 2016. R: A language and environment for statistical computing. Vienna (Austria): $\mathrm{R}$ foundation for statistical computing; [accessed 2016 Oct 10]. https://www.R-project.org/.

Sarralde R, Ariz J, Delgado de Molina A, Pallarés P, Santana JC. 2005. Datos sobre la actividad de la flota atunera española de cerco y barcos de apoyo pescando en el Océano Atlántico, obtenidos por observadores a bordo desde 2001 al 2004. Col. Vol. Sci. Pap. ICCAT. 58(1):359-371. 
Scales KL, Hazen EL, Jacox MG, Castruccio F, Maxwell SM, Lewison RL, Bograd SJ. 2018. Fisheries bycatch risk to marine megafauna is intensified in Lagrangian coherent structures. Proc Natl Acad Sci USA. 115(28):7362-7367. https://doi.org/10.1073/pnas.1801270115

Su NJ, Sun CL, Punt AE, Yeh SZ. 2008. Environmental and spatial effects on the distribution of blue marlin (Makaira nigricans) as inferred from data for longline fisheries in the Pacific Ocean. Fish Oceanogr. 17(6):432-445. https://doi.org/10.1111/j.1365-2419.2008.00491.x

Trasviña A, Barton ED. 2008. Summer circulation in the Mexican tropical Pacific. Deep Sea Res Part I. 55(5):587-607. https://doi.org/10.1016/j.dsr.2008.02.002

Torres-Orozco E, Trasviña A, Muhlia-Melo A, Ortega-García S. 2005. Dinámica de mesoescala y capturas de atún aleta amarilla en el Pacífico mexicano = Mesoscale dynamics and yellowfin tuna catches in the Mexican Pacific. Cienc Mar. 31(4):671-683.

https://doi.org/10.7773/cm.v31i4.33

Wang C, Enfield DB. 2001. The tropical western hemisphere warm pool. Geophys Res Lett. 28(8):1635-1638. https://doi.org/10.1029/2000GL011763
Wood SN. 2006. Generalized Additive Models: An Introduction with R. 1st ed. Florida: Chapman and Hall/CRC. 410 p.

Zainuddin M, Saitoh K, Saitoh SI. 2008. Albacore (Thunnus alalunga) fishing ground in relation to oceanographic conditions in the western North Pacific Ocean using remotely sensed satellite data. Fish Oceanogr. 17(2):61-73. http://dx.doi.org/10.1111/j.1365-2419.2008.00461.x

Zamudio L, Hurlburt HE, Metzger EJ, Tilburg CE. 2007. Tropical wave-induced oceanic eddies at Cabo Corrientes and the María Islands, Mexico. J Geophys Res. 112(C05048):1-17. https://doi.org/10.1029/2006JC004018

Zaytzev O, Cervantes-Duarte R, Montante O, Gallegos-García A. 2003. Coastal upwelling activity on the Pacific shelf of the Baja California peninsula. J Oceanogr. 59:489-502. https://doi.org/10.1023/A:1025544700632

Zuur AF, Ieno EN, Walker NJ, Saveliev AA, Smith GM. 2009. Mixed Effects Models and Extensions in Ecology with R. New York(NY): Springer-Verlag. 574 p. https://doi.org/10.18637/jss.v032.b01

Received June 2019, accepted January 2020. 

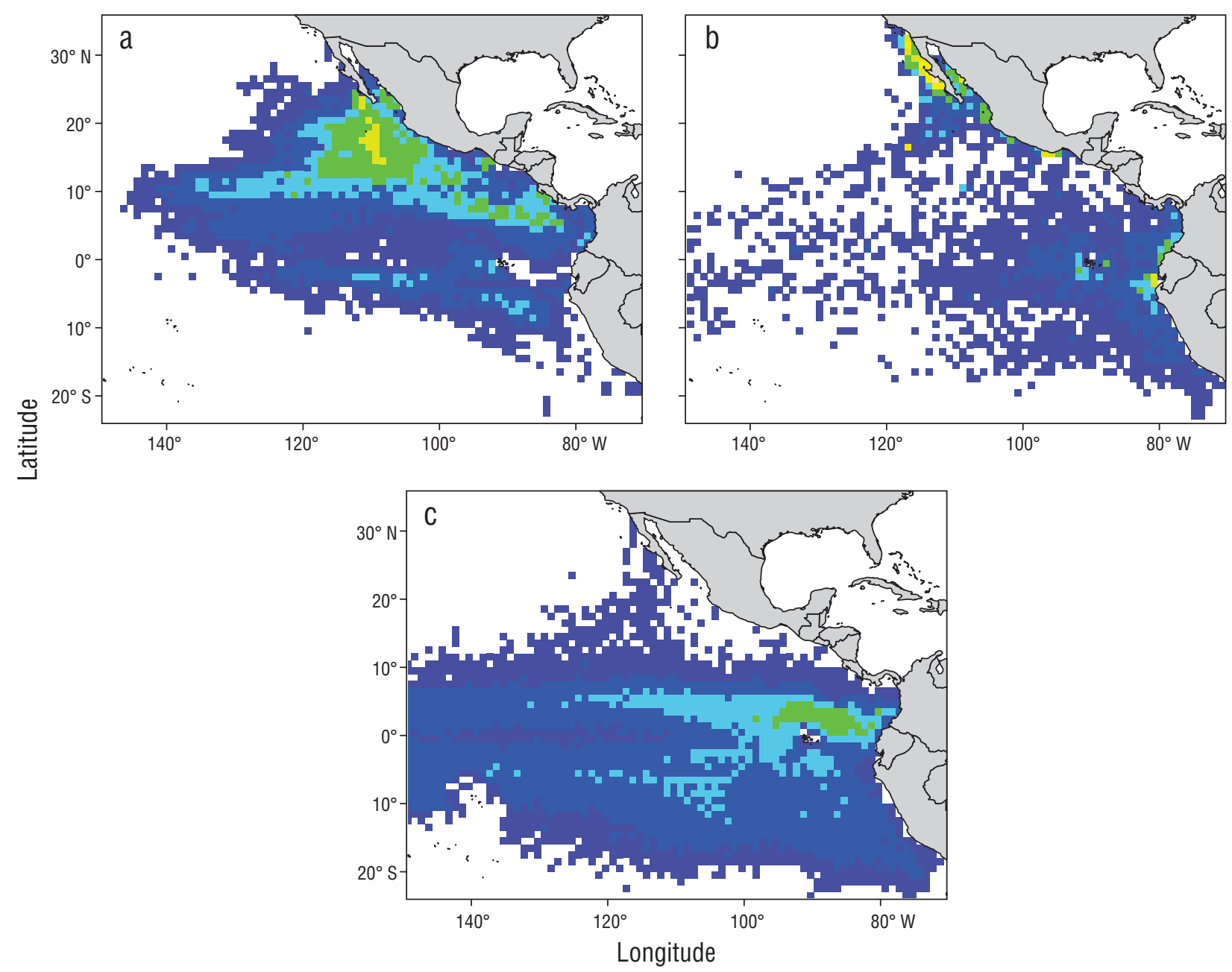

1-10 $\square$ 10-50 $\square$ 50-100 $\square$ 100-300 $\square$ 300-500 $\square$ 500-1000 $\square>1000$

Figure. S1. Fishing effort by the tuna purse seine fleet that operated in the eastern Pacific Ocean from August 2003 to December 2015 using dolphins (a), unassociated tuna schools (b), and floating objects (c) as fishing indicators. Color scale indicates number of sets.

Figura. S1. Esfuerzo pesquero de la flota de túnidos que operó con red de cerco en el océano Pacífico oriental desde agosto de 2003 hasta diciembre de 2015 utilizando delfines (a), cardúmenes de túnidos no asociados (b) y objetos flotantes (c) como indicadores de pesca. La escala de colores indica el número de lances. 